\title{
Polychaetes from Jan Mayen (Annelida, Polychaeta)
}

\author{
Torkild Bakken, ${ }^{1}$ Jon Anders Kongsrud, ${ }^{2}$ Eivind Oug, ${ }^{3}$ Sabine K.J. Cochrane,${ }^{4}$ Toril Loennechen Moen ${ }^{1}$ \& \\ Beata E.B. Solbakken ${ }^{1}$ \\ 1 Museum of Natural History and Archaeology, Norwegian University of Science and Technology, N0-7491 Trondheim, Norway \\ 2 Bergen Museum, University of Bergen, PO Box 7800, NO-5020 Bergen, Norway \\ 3 Norwegian Institute for Water Research, Southern Branch, Televeien 3, NO-4879 Grimstad, Norway \\ 4 Akvaplan-Niva AS, Polar Environmental Centre, NO-9295 Tromsø, Norway
}

\section{Keywords}

Distribution; diversity; Jan Mayen; Nordic seas; Norwegian Sea; Polychaeta.

\section{Correspondence \\ Torkild Bakken, Museum of Natural History and Archaeology, Norwegian University of Science and Technology, NO-7491 \\ Trondheim, Norway. E-mail: \\ torkild.bakken@vm.ntnu.no}

doi:10.1111/j.1751-8369.2009.00132.x

\begin{abstract}
A thorough literature review has been undertaken to establish the first complete account of polychaetes recorded from the area around the volcanic island of Jan Mayen. The annotated checklist lists 121 species-level taxa, representing an increase from the 75 species previously recorded. The checklist is based on existing records, supplemented with material sampled in 1999, from which 42 species new to the area were reported. Some previously reported species from the area have been excluded because of inadequate documentation. The polychaete fauna of Jan Mayen is comparable with that of the mainland Norwegian coast and the Svalbard area. No taxa unique to the island were found. However, knowledge of the marine invertebrate fauna in general at Jan Mayen is sparse because few surveys have been undertaken there. It is expected that future expeditions will reveal further new taxon records for the area.
\end{abstract}

In the northern waters around Svalbard and the volcanic island of Jan Mayen, a total of 1708 marine benthic macrofaunal organisms have been recorded. However, only 547 of these records are from Jan Mayen (Gulliksen et al. 1999). Although recently updated, the list of taxon records from Jan Mayen is very short, including 607 benthic species, of which 75 are polychaetes (Gulliksen et al. 2004). This most likely reflects the sparse sampling of marine benthic fauna that has been carried out around Jan Mayen (Gabrielsen et al. 1997; Gulliksen et al. 2004), and highlights our still superficial knowledge of the biodiversity in this area.

The most comprehensive survey was carried out in 1972 after the volcanic eruption in 1970 (Gulliksen 1974a). As a result of this survey, a series of papers was published on different taxonomic groups: ascidians (Gulliksen 1974b), echinoderms (Skjæeveland 1973), molluscs (Sneli \& Steinnes 1975; Sneli 1977) and sponges (Tendal 1983). Surveys in 1978, 1994 and 1999 investigated the succession patterns of faunal colonization on the newlyformed land (Gulliksen et al. 2004).

Polychaetes from Jan Mayen have never been studied explicitly, but several species were reported from the 1972 survey (Gulliksen 1974a), and also in later follow-up studies (Gulliksen et al. 1980; Gulliksen et al.
2004). From the general area, several other species were recorded in early expedition reports, such as the Norwegian North Atlantic Expedition of 1876-78 (Hansen 1879a, b, 1880, 1882), the Austrian expedition of 1882-83 (von Marenzeller 1886) and the Danish Ingolf Expedition of 1895-96 (Ditlevsen 1917; Wesenberg-Lund 1950).

This paper presents an updated and annotated checklist of polychaetes from Jan Mayen and the surrounding waters, compiled from existing records from the earliest expeditions to the most recent studies. Older records have been checked for synonyms, and polychaetes from the 1972 expedition (Gulliksen 1974a) were re-examined and records amended as appropriate. New (unpublished) polychaete material collected in 1999 is identified, and the taxon list and station data are presented. This list is intended to serve as a reference for regional comparisons and other environmental studies. Future studies may investigate temporal changes in the area, as well as further address the taxonomic issues highlighted here.

\section{Study area}

The island of Jan Mayen $\left(70^{\circ} 49^{\prime}-71^{\circ} 10^{\prime} \mathrm{N}, 07^{\circ} 56^{\prime}-\right.$ $09^{\circ} 05^{\prime} \mathrm{W}$ ) has an isolated location between the Greenland 


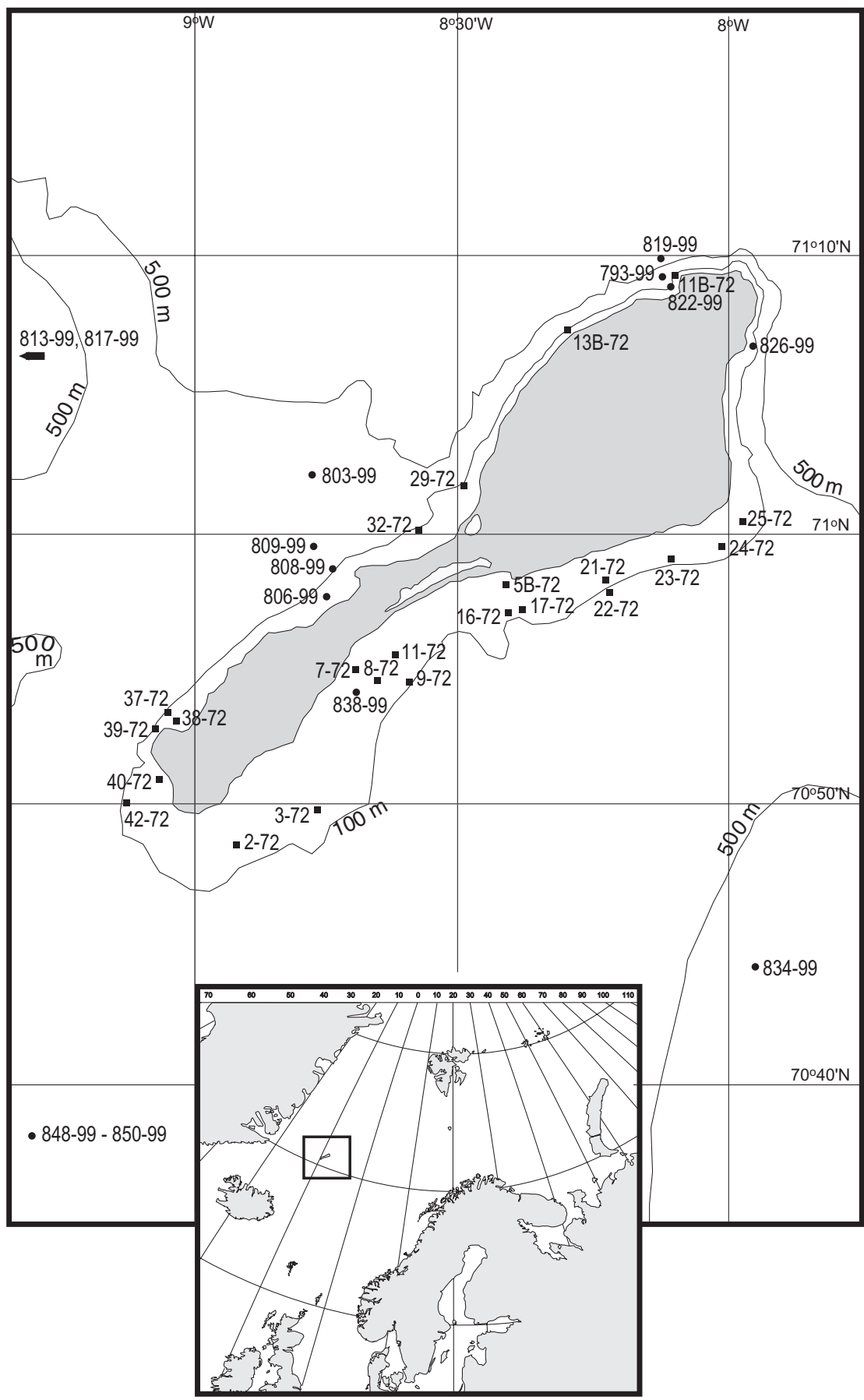

Fig. 1 Map of Jan Mayen Island and the surrounding waters. Stations where polychaetes were collected in $1972(\boldsymbol{\square})$ and $1999(\bullet)$ are shown. The positions of the stations from 1972 are based on the map in Gulliksen (1974a: fig. 1). The details for the 1999 stations are given in Table 1.
Sea, Iceland Sea and the Norwegian Sea (Fig. 1). It is surrounded by deep basins in the Greenland Sea to the north and in the Norwegian Sea to the east, and the somewhat shallower Iceland plateau to the south. The island is of volcanic origin, and is part of the Mid-Atlantic Ridge. During the most recent volcanic eruptions in 1970, lava flowed into the sea, and a new coastal platform extending over approximately $4 \mathrm{~km}^{2}$ was formed, in the north-eastern part of the island (Gulliksen et al. 1980).
The bottom topography around Jan Mayen is heterogeneous. To the east and south-east there is a small shelf at depths down to $150-250 \mathrm{~m}$, and a similar flatbottomed shelf with depths between 300 and $600 \mathrm{~m}$ extends from the south-west to the north-west. North and north-east of the island, the bottom topography slopes steeply down to a depth of $2000 \mathrm{~m}$ into the Jan Mayen Channel (Blindheim 2004). The water masses around Jan Mayen are a mixture of cold Arctic Water 
(ArW; bottom temperatures down to $-0.3^{\circ} \mathrm{C}$ and salinities around 34.4-34.6) from the Arctic Ocean, transported southwards by the East Greenland Current, and warmer, more saline Atlantic Water (AW; temperature from around $1^{\circ} \mathrm{C}$ at bottom to $5^{\circ} \mathrm{C}$ on surface, and salinity around 34.9), penetrating northwards via the North Atlantic Current (Gulliksen et al. 1980). In addition to the surface currents, cold water from the Arctic Ocean flows as deep bottom currents under the East Greenland Current in the southern part of the Greenland Sea (Blindheim 2004).

The meeting of ArW and AW forms the Arctic Front, where complex patterns of turbulence occur (Sundfjord et al. 2007 and references therein). Usually the Arctic Front is situated south of the island, giving a dominance of Arctic water at Jan Mayen. However, because the distribution of water masses and currents fluctuate within the area (Gabrielsen et al. 1997; Blindheim 2004), there may be variable AW influence. Salinity and temperature profiles recorded in 1999 at a number of stations are given in Lønne (1999). The ice front often reaches Jan Mayen during the oceanographic winter, but there are considerable interannual variations. Drift ice frequently surrounds the island from February to April.

\section{Methods and materials}

The material from 1999 arises from an extensive sampling programme carried out during 12-19 September 1999 from the RV Jan Mayen. The sampling scheme encompassed different substrates and depth intervals, from intertidal to $770 \mathrm{~m}$ in depth (Fig. 1; Table 1). On soft substrates, epifauna and hyperbenthos were collected using Sneli (Sneli 1998) and Rothlisberg and Pearcy (RP) (Brattegard \& Fosså 1991) sledges, with collecting times of 15 and $20 \mathrm{~min}$, respectively. Quantitative samples of infauna were taken at some stations using a $0.1-\mathrm{m}^{2}$ van Veen grab, and sieved through a $1-\mathrm{mm}$ round-pore diameter mesh screen. On gravel and rocky substrates a triangular dredge (side length $0.9 \mathrm{~m}$ ) was used, with a collecting time of $5 \mathrm{~min}$. In shallow subtidal waters qualitative samples were taken by SCUBA diving.

The 1972 material was sampled in August from the sea rescue vessel RK Sjøfareren (Gulliksen 1974a). Mostly hard bottoms and coarse substrates down to $100 \mathrm{~m}$ were sampled, using a triangular dredge and by SCUBA diving.

The material was fixed in the field using an approximately 8-15\% formalin-seawater solution (depending on the nature of the sample). Samples were later rinsed in freshwater, sorted into higher taxa and preserved in $70-80 \%$ ethanol. Identification was carried out using morphological features under light microscopy. All specimens are deposited in the collections of the Museum of Natural History and Archaeology, Norwegian University of Science and Technology, Trondheim.

\section{Results and discussion}

A total of 67 polychaete taxa were identified from the material from 1999 (Table 2), of which 42 are new records for Jan Mayen. As far as possible, identifications were made to species level, but some taxa are identified to genus level, and informally distinguished from named species, such as Capitella sp. A, Capitella sp. B, Chaetozone

\begin{tabular}{|c|c|c|c|c|c|}
\hline Date & Station & Latitude (N) & Longitude (W) & Depth (m) & Sampling gear \\
\hline 13/09/1999 & 793-99 & $71^{\circ} 09.41$ & $8^{\circ} 06.65$ & 49 & Diving \\
\hline 14/09/1999 & 803-99 & $71^{\circ} 02.34$ & $8^{\circ} 44.90$ & 451 & RP sledge $\mathrm{e}^{\mathrm{a}}$ \\
\hline 14/09/1999 & 806-99 & $70^{\circ} 57.98$ & $8^{\circ} 45.23$ & 46 & van Veen grab \\
\hline 14/09/1999 & $808-99$ & $70^{\circ} 58.61$ & $8^{\circ} 46.41$ & 109 & van Veen grab \\
\hline 14/09/1999 & $809-99$ & $70 \circ 59.39$ & $8^{\circ} 48.73$ & 269 & Triangular dredge \\
\hline 15/09/1999 & $813-99$ & $71^{\circ} 06.41$ & $9^{\circ} 35.26$ & 514 & RP sledge \\
\hline 15/09/1999 & $817-99$ & $71^{\circ} 04.94$ & $9^{\circ} 27.53$ & 142 & Sneli sledge \\
\hline 15/09/1999 & $819-99$ & $71^{\circ} 10.18$ & $8^{\circ} 06.54$ & 534 & Triangular dredge \\
\hline 15/09/1999 & $822-99$ & $71^{\circ} 09.38$ & $8^{\circ} 06.63$ & 44 & van Veen grab \\
\hline 15/09/1999 & $826-99$ & $71^{\circ} 06.21$ & $7^{\circ} 57.54$ & 54 & Diving \\
\hline 16/09/1999 & 834-99 & $70^{\circ} 45.07$ & $7^{\circ} 57.74$ & 771 & RP sledge \\
\hline 16/09/1999 & $838-99$ & $70^{\circ} 53.04$ & $8^{\circ} 43.61$ & 39 & Sneli sledge \\
\hline 17/09/1999 & $848-99$ & $70^{\circ} 38.87$ & $9^{\circ} 22.33$ & 599 & RP sledge \\
\hline 17/09/1999 & $849-99$ & $70^{\circ} 37.34$ & $9^{\circ} 20.30$ & 390 & Sneli sledge \\
\hline 17/09/1999 & $850-99$ & $70^{\circ} 36.19$ & $9^{\circ} 20.72$ & 313 & RP sledge \\
\hline
\end{tabular}

${ }^{\mathrm{a}}$ Rothlisberg and Pearcy sledge. 
Table 2 Polychaete species represented in the material examined from the 1999 cruise to Jan Mayen.

\begin{tabular}{|c|c|}
\hline Family & Species \\
\hline Euphrosinidae & Euprosine borealis Ørsted, 1843 \\
\hline Polynoidae & Bylgides groenlandica (Malmgren, 1867) \\
\hline Pholoidae & Pholoe assimilis Ørsted, 1844 \\
\hline Phyllodocidae & Paranaitis wahlbergi (Malmgren, 1865) \\
\hline Phyllodocidae & Phyllodoce groenlandica Ørsted, 1842 \\
\hline Phyllodocidae & Eteone cf. longa (O. Fabricius, 1780) \\
\hline Nephtyidae & Nephtys ciliata (O.F. Müller, 1776) \\
\hline Nephtyidae & Nephtys paradoxa Malm, 1874 \\
\hline Nephtyidae & Nephtys pente Rainer, 1984 \\
\hline Sphaerodoridae & Ephesiella abyssorum Hansen, 1878 \\
\hline Sphaerodoridae & Sphaerodoropsis minuta (Webster \& Benedict, 1887) \\
\hline Sphaerodoridae & Sphaerodoropsis philippi (Fauvel, 1911) \\
\hline Sphaerodoridae & Sphaerodorum flavum Ørsted, 1843 \\
\hline Onuphide & Hyalinoecia tubicola (O.F. Müller, 1776) \\
\hline Onuphide & Nothria conchylega (M. Sars, 1835) \\
\hline Lumbrineridae & Abyssoninoe cf. abyssorum (McIntosh, 1885) \\
\hline Lumbrineridae & Scoletoma fragilis (O.F. Müller, 1776) \\
\hline Dorvilleidae & Ophyotrocha sp. A \\
\hline Dorvilleidae & Parougia nigridentata (Oug, 1978) \\
\hline Orbiniidae & Scoloplos armiger (O. F. Müller, 1776) \\
\hline Orbiniidae & Scoloplos arctica (Hansen, 1879) \\
\hline Spionidae & Polydora caulleryi Mesnil, 1897 \\
\hline Spionidae & Polydora socialis (Schmarda, 1861) \\
\hline Spionidae & Prionospio cirrifera Wirén, 1883 \\
\hline Spionidae & Spio filicornis (O.F. Müller, 1776) \\
\hline Spionidae & Spio goniocephala Thulin, 1957 \\
\hline Spionidae & Spiophanes kroeyeri Grube, 1860 \\
\hline Spionidae & Pygospio elegans Claparède, 1863 \\
\hline Poecilochaetidae & Poecilochaetus serpens Allen, 1904 \\
\hline Paraonidae & Aricidea quadrilobata Webster \& Benedict, 1887 \\
\hline Paraonidae & Aricidea suecica Eliason, 1920 \\
\hline Paraonidae & Levinsenia gracilis (Tauber, 1920) \\
\hline Paraonidae & Paradoneis eliasoni Mackie, 1991 \\
\hline Cirratulidae & Chaetozone christiei Chambers, 2000 \\
\hline Cirratulidae & Chaetozone sp. C \\
\hline Cirratulidae & Chaetozone setosa Malmgren, 1867 \\
\hline Acrocirridae & Macrochaeta polyonyx Eliason, 1962 \\
\hline Opheliidae & Ophelina cylindricaudata (Hansen, 1879) \\
\hline Opheliidae & Travisia forbesii Johnston, 1840 \\
\hline Scalibregmatidae & Scalibregma inflatum Rathke, 1843 \\
\hline Scalibregmatidae & Pseudoscalibregma parvum (Hansen, 1879) \\
\hline Capitellidae & Capitella sp. A \\
\hline Capitellidae & Capitella sp. B \\
\hline Capitellidae & Heteromastus filiformis Claparède, 1864 \\
\hline Capitellidae & Notomastus latericeus M. Sars, 1851 \\
\hline Maldanidae & Nicomache quadrispinata Arwidsson, 1906 \\
\hline Maldanidae & Praxillella gracilis (M. Sars, 1861) \\
\hline Maldanidae & Praxillella praetermissa minor Arwidsson, 1907 \\
\hline Maldanidae & Macroclymene sp. A \\
\hline Maldanidae & Microclymene sp. A \\
\hline Maldanidae & Notoproctus oculatus arctica Arwidsson, 1907 \\
\hline Maldanidae & Rhodine gracilior Tauber, 1879 \\
\hline Oweniidae & Galathowenia oculata (Zaks, 1923) \\
\hline Oweniidae & Owenia polaris Koh, Bhaud \& Jirkov, 2003 \\
\hline Ampharetidae & Eclysippe vanelli (Fauvel, 1936) \\
\hline Ampharetidae & Glyphanostomum pallescens (Théel, 1879) \\
\hline Ampharetidae & Melinna elisabethae McIntosh, 1922 \\
\hline Ampharetidae & Melythasides laubieri Desbruyeres, 1978 \\
\hline Terebellidae & Lanassa venusta (Malm, 1874) \\
\hline Terebellidae & Laphania boecki Malmgren, 1866 \\
\hline Sabellidae & Chone duneri Malmgren, 1867 \\
\hline Sabellidae & Chone fauveli McIntosh, 1916 \\
\hline Sabellidae & Chone paucibranchiata (Krøyer, 1856) \\
\hline Sabellidae & Euchone analis (Krøyer, 1856) \\
\hline Sabellidae & Laonome kroyeri Malmgren, 1865 \\
\hline Sabellidae & Bispira crassicornis (M. Sars, 1851) \\
\hline Serpulidae & Apomatus similis Marion \& Bobretzky, 1875 \\
\hline
\end{tabular}

sp. C, Macroclymene sp. A, Microclymene sp. A and Ophrytrocha sp. A. These may represent undescribed species or morphological variants within less well-described groups. Further study of these is beyond the scope of the present work, but some problematic issues are remarked upon within the taxon list below. Furthermore, of the re-examined material collected in 1972, some specimens were missing from the museum collections, and could not be traced. These specimens are omitted from the present treatment and, as a consequence, there are some discrepancies between the list below and that of Gulliksen (1974a).

Based on the checklist presented here, 121 recognized polychaete taxa are recorded from Jan Mayen. This represents a threefold increase (Gulliksen et al. 1999) in our knowledge of the polychaete fauna of Jan Mayen. From North Atlantic waters, current records list a total of 656 polychaete taxa from mainland Norwegian coastal waters, and 259 from around Svalbard (Brattegard \& Holthe 1997; Gulliksen et al. 1999; Gulliksen et al. 2004). The fact that the present list from Jan Mayen is still relatively short may result from several factors. Firstly, the number of benthic studies conducted around Jan Mayen is low, compared with Svalbard and, especially, the mainland Norwegian coast (see Gulliksen et al. 1999; Gulliksen et al. 2004). Secondly, quantitative methods that take into account small organisms (retained on a $1-m m$ sieve) have only been used in the most recent studies; the earlier data were largely from SCUBA-diving and triangular-dredge samples, where polychaetes are usually under-represented. Thirdly, the faunal richness around Jan Mayen may be, in fact, lower than other areas as a result of its geological history, and the resulting more uniform topography and narrower range of available habitats.

As might be expected from the hydrology of the area, the species reported from around Jan Mayen are typical for north Altlantic waters, and only a few are not previously reported from the Norwegian coast, such as Abyssoninoe abyssorum, Bathyfauvelia affinis, Eusyllis monilicornis, Nicomache quadrispinata and the recently described Chaetozone christiei.

This checklist advances current knowledge of the biodiversity around Jan Mayen, but further sampling expeditions are to be encouraged, in order to achieve a more complete picture.

\section{Annotated checklist}

The list of polychaete taxa given below represents a compilation of data from the literature, supplemented with information from the newly-identified material. The geographic coverage is the shelf areas and immediate deep 
waters around Jan Mayen. Rather than giving a strict geographical definition, we have included deep water samples from expeditions with reported records from the Jan Mayen area.

In the list that follows, information for each species comprises species name, relevant synonymies, material examined, previous records, or previous reports, and remarks. The synonymies are restricted to reports from Jan Mayen only. "Material examined" refers to the material collected in 1972 and 1999. "Previous records" refers to cases in which the identity of the species has been confirmed, whereas "previous reports" refers to cases in which no material has been examined. Species records that are invalid because of taxonomic revisions or obvious misidentifications are marked with an asterisk preceding the species name. These are not included in calculations of numbers of taxa recorded from the fauna of Jan Mayen.

For material examined, the number of specimens from each station is given in parentheses following the station number. The Norwegian North Atlantic Expedition (Hansen 1879a, b, 1880, 1882) is abbreviated as NNAE. The Ingolf Expedition is refered to simply as Ingolf.

The terebellomorh polychaetes from the area have been studied in detail by Holthe (1986). He examined most of the specimens reported earlier by others, and hence records noted by Holthe (1986) may not represent new records. Holthe also identified the polychaete material reported in Gulliksen (1974a) and Gulliksen et al. (1980).

\section{Euphrosinidae}

Euphrosine borealis Ørsted, 1843

Material examined. Station (stn) 826-99 (1).

\section{Polynoidae}

Bylgides annenkovae Pettibone, 1993

Antinoëlla sarsi sarsi. - Gulliksen 1974a: 23.

Bylgides annenkovae Pettibone, 1993: 11-14, figs. 6-7. Pettibone in Loshamn 1980: 214-117, figs. 105-106.

Material examined. Stns 3-72 (10), 17-72 (3), 29-72 (1), 42-72 (3).

Previous records. Stns 3-72 (4), 17-72 (3), 29-72 (1), 42-72 (3), Gulliksen (1974a) and Loshamn (1980).

Remarks. Specimens identified as Antinoëlla sarsi sarsi (Gulliksen, 1974a) were revised and identified as Bylgides annenkovae by Loshamn (1980). In his unpublished Master's thesis, Loshamn gave a full species description (in Norwegian) as well as the name of the species later to be formally described by Pettibone (1993).
Bylgides groenlandica (Malmgren, 1867)

Harmothoe badia. - Ditlevsen 1917: 22-23 (?).

Material examined. Stn 834-99 (1).

Previous reports Ingolf stn 116, 23 July 1896, $70^{\circ} 05^{\prime} \mathrm{N}$, $8^{\circ} 26^{\prime} \mathrm{W}, 699 \mathrm{~m}$ depth (Ditlevsen 1917).

Remarks. One specimen with regenerating abdomen and lacking elytra was found. The identification is primarily based on chaetae as described by Pettibone (1993). Théel (1879) included several taxa today recognized as valid species in his Polynoe badia, among them Bylgides groenlandica and Bylgides promamme (Loshamn 1980; Pettibone 1993). The identity of the specimens Ditlevsen (1917) reported on from Jan Mayen is therefore uncertain, but most probably Bylgides groenlandica was represented.

\section{*Bylgides sarsi Malmgren, 1865}

Harmothoe sarsi. - Ditlevsen 1917: 23-24.

Antinoë sarsi. - von Marenzeller 1886: 20. - Fauvel 1946: 398.

Previous reports. Jan Mayen, 40 m depth (von Marenzeller 1886); off Jan Mayen, about $100 \mathrm{~m}$ depth (Ditlevsen 1917); Jan Mayen, Drivtømmerbukt (Fauvel 1946).

Remarks. This species has been widely reported in the literature. Because of the distribution of Bylgides sarsi, as well as a history of misidentified specimens, it is doubtful that the true Bylgides sarsi has been recorded from Jan Mayen (Pettibone 1993). The material previously reported from Jan Mayen should be revised.

Eunoe nodosa (M. Sars, 1861)

Polynoe (Eunoe) islandica Hansen, 1879a: 2-3, table II, figs. 1-7.

Polynoe arctica Hansen, 1879b: 267-268, table I, figs. 1-5. Polynoe spinnulosa Hansen, 1880: 225-226, table II, figs. 6-10.

Eunoe scabra. - von Marenzeller 1886: 19.

Harmothoe nodosa. - Ditlevsen 1917: 6-8, pl. II, fig. 1; pl. III, fig. 10.

Eunoe nodosa. - Gulliksen 1974a: 23. - Loshamn 1980: 185-189, fig. 91.

Material examined. Stn 23-72 (2).

Previous records. NNAE stn 223, 1 Aug. 1877, $70^{\circ} 54^{\prime} \mathrm{N}$, $8^{\circ} 24^{\prime} \mathrm{W}, 128 \mathrm{~m}$ depth; NNAE stn 224, l Aug. 1877, $70^{\circ} 51^{\prime} \mathrm{N}, 8^{\circ} 20^{\prime} \mathrm{W}, 174 \mathrm{~m}$ depth; NNAE stn 237, 3 Aug. $1877,70^{\circ} 41^{\prime} \mathrm{N}, 10^{\circ} 10^{\prime} \mathrm{W}, 481 \mathrm{~m}$ depth (Hansen 1882); Jan Mayen, 100-140 m depth (von Marenzeller 1886); Jan Mayen, 105 m depth (Ditlevsen 1917); stns 3-72 (3), 23-72 (2) Gulliksen (1974a).

Remarks. The specimens from station 3-72 reported by Gulliksen (1974a) could not be retrieved. Loshamn (1980) examined the material sampled in 1972 (Gullik- 
sen 1974a). He discussed the similarity of Eunoe nodosa to Harmothoe vittata Trautzsch, 1889, a species found in Svalbard, that Loshamn believed should belong to Eunoe. Because of problems regarding earlier synonymies of Eunoe nodosa and Eunoe oerstedi, the records cited above should be treated with care (Loshamn 1980). The three species described by Hansen (1879a, b, 1880) were considered synonyms of Eunoe nodosa by Loshamn (1980), but he did not comment further on their status.

\section{${ }^{*}$ Eunoe oerstedi Malmgren, 1865}

Eunoe oerstedi. - Loshamn 1980: 181-185, figs. 89-90.

Previous reports. Ditlevsen 1917 as Harmothoe nodosapossible record.

Remarks. Eeunoe oerstedi has been synonymized with Eunoe nodosa in the literature (Loshamn 1980), but they were considered separate species by Pettibone (1954), which has been followed ever since. As a result, earlier records must be treated with care (Loshamn 1980). Gulliksen et al. (1999) cited Eunoe oerstedi from Jan Mayen, which is most likely to be based on the record of Eunoe nodosa by Ditlevsen (1917) (see above). Loshamn (1980) outlined the problem with this species, but did not place Eunoe oerstedi on his list of confirmed identifications from Jan Mayen.

\section{Harmothoe fragilis Moore, 1910}

Harmothoe fragilis. - Gulliksen 1974a: 23. - Loshamn 1980: 115-119, fig. 55.

Material examined. Stns 22-72 (2), 23-72 (1), 37-72 (1)

Previous records. Stns 23-72 (1), 37-72 (1) Gulliksen (1974a).

Remarks. The material examined here has previously been revised by Loshamn (1980). Harmothoe fragilis is close to Harmothoe impar. Loshamn (1980) commented that before 1910, most specimens were probably identified as Harmothoe impar. Also, later accounts have treated Harmothoe fragilis as a synonym of Harmothoe impar.

Harmothoe imbricata (L., 1767)

Harmothoe imbricata. - Ditlevsen 1917: 10-12.

Previous reports. $70^{\circ} 21^{\prime} \mathrm{N} 8^{\circ} 25^{\prime} \mathrm{W}$, about $300 \mathrm{~m}$ depth (Ditlevsen 1917).

\section{Harmothoe impar (Johnston, 1839)}

Evarne impar. - von Marenzeller 1886: 19-20.

Previous reports. Jan Mayen, 140-230 m depth (von Marenzeller 1886).

Remarks. Several reports of Harmothoe impar should be referred to Harmothoe fragilis (Loshamn 1980). The present report by von Marenzeller (1886) is dubious. Verified records of Harmothoe impar suggest that this species has a more southern distribution (Loshamn 1980).

Harmothoe globifera (G.O. Sars, 1873)

Harmothoe globifera. - Ditlevsen 1917: 9.

Previous reports. Ingolf stn 116, 23 July 1896, $70^{\circ} 05^{\prime} \mathrm{N}$, $8^{\circ} 26^{\prime} \mathrm{W}, 699 \mathrm{~m}$ depth (Ditlevsen 1917).

\section{Harmothoe rarispina (M. Sars, 1861)}

Lagisca extenuata. - Ditlevsen 1917: 13-14. - WesenbergLund 1953: 25-26.

Previous reports. $70^{\circ} 21^{\prime} \mathrm{N} 8^{\circ} 25^{\prime} \mathrm{W}$, about $300 \mathrm{~m}$ depth (Ditlevsen 1917).

Remarks. Several authors (e.g. Fauvel 1923; Wesenberg-Lund 1953; Pettibone 1963) treat Harmothoe rarispina and Lagisca extenuata (= Harmothoe extenuata) as synonymous. Lagisca extenuata is described from the Mediterranean. Loshamn (1980) keeps the species separate, and indicates that Lagisca extenuata does not occur in North Atlantic waters.

\section{Macellicephala longipalpa Uschakov, 1957}

Macellicephala violacea. - Ditlevsen 1917: 39. - WesenbergLund 1953: 27.

Macellicephala longipalpa. - Pettibone 1976: 17, figs. 8-9.

Previous reports. Ingolf stn $116,70^{\circ} 05^{\prime} \mathrm{N}, 8^{\circ} 26^{\prime} \mathrm{W}$, $699 \mathrm{~m}$ depth; $70^{\circ} 32^{\prime} \mathrm{N}, 8^{\circ} 10^{\prime} \mathrm{W}, 880 \mathrm{~m}$ depth (Ditlevsen 1917).

Remarks. Specimens identified by Ditlevsen (1917) as Macellicephala violacea from the Ingolf Expedition sampled at Jan Mayen were revised by Pettibone (1976), and were found to belong to Macellicephala longipalpa.

Bathyfauvelia affinis (Fauvel, 1914)

Bathyfauvelia affinis. - Pettibone 1976: 35, figs. 21-22. Kirkegaard 1982: 254-259, table 2.

Previous reports. Swedish Polar Expedition 1900, $72^{\circ} 01^{\prime} \mathrm{N} 08^{\circ} 33^{\prime} \mathrm{W}, 2400 \mathrm{~m}$ depth (Pettibone 1976).

\section{Pholoidae}

Pholoe assimilis Ørsted, 1845

Material examined. Stns 803-99 (1), 834-99 (2), 848-99 (35).

Remarks. The specimens agree with characters given by Petersen (1998). They are pale, rather flattened and with elytrae covering the dorsum completely.

Pholoe minuta (O. Fabricius, 1780)

Pholoe minuta. - von Marenzeller 1886: 20. - Ditlevsen 1917: 49-50. - Wesenberg-Lund 1953: 28-29. - Gulliksen et al. 1980: 140 . 
Previous reports. Jan Mayen, 230-400 m depth (von Marenzeller 1886); Ingolf stn 115, 23 July 1896, 7050’ $\mathrm{N}$, $8^{\circ} 29^{\prime} \mathrm{W}, 162 \mathrm{~m}$ depth (Ditlevsen 1917); north part of Jan Mayen, 5-30 m depth (Gulliksen et al. 1980).

Remarks. Petersen (1998) noted that Pholoe minuta, which is a western Atlantic species, does not occur in European waters, from where several separate species have been confounded under this name. Jan Mayen lies within what could be a western Atlantic distribution, and the occurrence of Pholoe minuta is not unlikely. Specimens identified as Pholoe minuta should be revised.

\section{Phyllodocidae}

Eumida arctica (Annenkova, 1946)

Eulalia bilineata. - Wesenberg-Lund 1953: 32.

Eumida arctica. - Eibye-Jacobsen 1991: 97-99. - Pleijel 1993: 69-70, figs. 46-47.

Previous reports. Jan Mayen, $100 \mathrm{~m}$ depth (Wesenberg-Lund 1953; Eibye-Jacobsen 1991).

Remarks: The taxonomy of this species was discussed by Eibye-Jacobsen (1991) and Pleijel (1993).

\section{Eulalia hanssoni Pleijel, 1987}

Eulalia hanssoni. - Pleijel 1993: 94-97, figs. 66-68.

Previous reports. Jan Mayen (Pleijel 1993).

*Eteone picta Quatrefages, 1866

Eteone picta. - Fauvel 1946: 398.

Previous reports. South-east coast of Jan Mayen (Fauvel 1946).

Remarks. Wesenberg-Lund (1953) doubted Fauvel's (1946) record, considering that Eteone picta has a southern (Lusitanian) distribution. According to Pleijel (1993), it is not found north of the British Isles.

Eteone cf. longa (O. Fabricius, 1780)

Eteone longa. - Gulliksen 1974a: 23.

Material examined. Stns 40-72 (1), 806-99 (21), 808-99 (29), 822-99 (3).

Previous records: Stn 40-72 (1) Gulliksen (1974a).

Remarks. Specimens are identified to Eteone cf. longa according to Pleijel (1993). This species belongs in a species group with Eteone flava, where species identities are unclear (Pleijel 1993).

*Paranaitis near polynoides (Moore, 1909)

Paranaitis near polynoides. - Pleijel 1993: 26-28, fig. 16.

Previous reports. Jan Mayen, $70^{\circ} 40^{\prime} \mathrm{N}, 07^{\circ} 38^{\prime} \mathrm{W}, 1236-$ 1243 m depth, 1 specimen (Pleijel 1993).

Remarks. Pleijel (1993) reported Paranaitis near polynoides from Jan Mayen. He stated that the identifica- tion was uncertain, and that the specimens might represent an undescribed species. Kato \& Pleijel (2003) later revised Paranaitis, and found Paranaitis polynoides to occur only in the Pacific, and that Atlantic specimens previously assigned to Paranaitis polynoides belong to a different species. They did not, however, mention the material referred to by Pleijel (1993). It is unlikely that this species is found in the North Atlantic, but the specimens from Jan Mayen referred to in Pleijel (1993) should be re-examined.

\section{Paranaitis wahlbergi (Malmgren, 1865)}

Anaitis wahlbergi. - Ditlevsen 1917: 61. - Wesenberg-Lund 1953: 30.

Material examined. Stn 834-99 (1).

Previous records. Off Jan Mayen, about $100 \mathrm{~m}$ depth (Ditlevsen 1917, Wesenberg-Lund 1953; based on the same single record).

\section{Phyllodoce groenlandica Ørsted, 1842}

Phyllodoce groenlandica. - Fauvel 1946: 398.

Anaitides mucosa. - Gulliksen 1974a: 23.

Material examined. Stns 3-72 (3), 16-72 (1), 17-72 (1), 25-72 (1), 32-72 (1), 806-99 (2), 808-99 (1), 822-99 (1).

Previous records. RV Pourquoi-Pas? 1929 stn VIII, Jan Mayen (Fauvel 1946); stns 3-72, 16-72, 17-72, 25-72, 32-72 (Gulliksen 1974a).

Remarks: Re-examination of specimens identified to Anaitides mucosa from the 1972 cruise (Gulliksen 1974a) revealed that all specimens belonged to Phyllodoce groenlandica.

\section{Hesionidae}

Nereimyra punctata (O.F. Müller, 1776)

Castalia punctata. - von Marenzeller 1886: 20.

Previous reports. Jan Mayen, 230-400 m depth (von Marenzeller 1886).

Remarks. Nereimyra punctata has been redescribed, and has been found to be a common species in the North Atlantic (Nygren et al. 2005).

\section{Syllidae}

Autolytinae indet.

Autolytinae sp. indet. - Gulliksen 1974a: 23.

Material examined. Stn 5B-72 (1).

Previous records. Stn 5B-72 (Gulliksen 1974a).

Remarks. The specimen is not well preserved, and was not possible to identify further. 
Eusyllis blomstrandi Malmgren, 1867

Eusyllis monilicornis. - von Marenzeller 1886: 21.

Eusyllis blomstrandi. - Wesenberg-Lund 1953: 38.

Previous reports. Jan Mayen, 20-400 m depth (von Marenzeller 1886).

\section{Eusyllinae sp.}

Syllinae sp. indet. - Gulliksen 1974a: 23.

Material examined. Stns 13B-72 (2), 793-99 (1), 822-99 (4), 834-99 (1).

Previous records: Stn 13B-72 (2) (Gulliksen 1974a).

Remarks. These specimens were assigned to Eusyllinae, and have not been available for further identification.

Syllis armillaris (O.F. Müller, 1776)

Syllis armillaris. - Fauvel 1946: 398.

Previous reports. Jan Mayen, south-east coast (Fauvel 1946).

Syllis cornuta (Rathke, 1843)

Syllis cornuta. - Wesenberg-Lund 1950: 15-16.

Previous reports. Ingolf stn 115, 23 July 1896, 7050' N, $8^{\circ} 29^{\prime} \mathrm{W}, 162 \mathrm{~m}$ depth (Wesenberg-Lund 1950).

\section{Syllis fasciata Malmgren, 1867}

Typosyllis fasciata. - von Marenzeller 1886: 20.

Syllis fasciata. - Wesenberg-Lund 1947: 10-11.

Previous reports. Jan Mayen, 20-400 m depth (von Marenzeller 1886); Jan Mayen, about $20 \mathrm{~m}$ depth, 26 June 1900, Søren Jensen (Wesenberg-Lund 1947).

\section{Nereididae}

Nereis pelagica L., 1758

Nereis pelagica. - Wesenberg-Lund 1953: 40. - Gulliksen et al. 1980: 140.

Material examined. Stns 11B-72 (1), 17-72 (1), 24-72 (3).

Previous records. Stns 11B-72 (1), 17-72 (1), 24-72 (3) Gulliksen (1974a); northern part of Jan Mayen, 5-30 m depth (Gulliksen et al. 1980).

Remarks. Wesenberg-Lund (1953) referred to Hansen (1882) for a record from Jan Mayen. This is, however, a literature reference by Hansen, and cannot be related to any records from the Norwegian North Atlantic Expedition (Hansen 1879a, b, 1880, 1882). This record therefore cannot be verified.

Nereis zonata Malmgren, 1867

Nereis zonata. - Wesenberg-Lund 1950: 20.

Previous reports. RV Ryder, $70^{\circ} 21^{\prime} \mathrm{N}, 8^{\circ} 25^{\prime} \mathrm{W}, 300 \mathrm{~m}$ depth (Wesenberg-Lund 1950).

\section{Nephtyidae}

Nephtys ciliata (O.F. Müller, 1776)

Material examined. Stns 803-99 (1), 834-99 (1).

Remarks. All specimens reported by Gulliksen (1974a) were re-examined and found to belong to Nephtys pente Rainer, 1984. This species was described after identification of the specimens from the 1972 cruise (see below).

Nephtys paradoxa Malm, 1874

Material examined. Stns 808-99 (5), 819-99 (1), 849-99 (2).

\section{Nephtys pente Rainer, 1984}

Nephtys ciliata. - Gulliksen 1974a: 23.

Material examined. Stns 2-72 (2), 16-72 (1), 17-72 (5), 23-72 (36), 25-72 (6), 29-72 (4), 42-72 (4), 806-99 (1), 808-99 (1), 819 (1), 838-99 (1).

Previous records. Gulliksen (1974a) as Nephtys ciliata.

Remarks. A re-examination of the specimens collected in 1972 (Gulliksen 1974a) and identified to Nephtys ciliata proved to be Nephtys pente, following Rainer's (1991) revision.

\section{Sphaerodoridae}

Ephesiella abyssorum Hansen, 1878

Ephesia peripatus. - Wesenberg-Lund 1950: 22-23. - 1953: 47.

Material examined. Stns 813-99 (8), 834-99 (9), 848-99 (35), 850-99 (15).

Previous records. $70^{\circ} 32^{\prime} \mathrm{N}, 8^{\circ} 10^{\prime} \mathrm{W}, 770 \mathrm{~m}$ depth (Wesenberg-Lund 1950).

Remarks. We follow the nomenclatorial reasoning of Hartman \& Fauchald (1971) in using Ephesiella abyssorum for this species.

Sphaerodoropsis minuta (Webster \& Benedict, 1887)

Sphaerodorum minutum. - Wesenberg-Lund 1950: 23. 1953: 47.

Material examined. Stns 803-99 (1), 813-99 (2), 834-99 (8), 848-99 (19), 850-99 (1).

Previous records. Jan Mayen, 75-112 m depth (Wesenberg-Lund 1950); $70^{\circ} 50^{\prime} \mathrm{N}, 8^{\circ} 29^{\prime} \mathrm{W}, 162 \mathrm{~m}$ depth (Wesenberg-Lund 1953).

Sphaerodoropsis philippi (Fauvel, 1911)

Material examined. Stns 813-99 (22), 834-99 (44), 848-99 (556), 850-99 (2).

Sphaerodorum flavum Ørsted, 1843

Ephesia gracilis. - von Marenzeller 1886: 22. - WesenbergLund 1953: 46. 
Material examined. Stns 813-99 (9), 834-99 (81), 848-99 (1).

Previous records. Jan Mayen, 140-400 m depth (von Marenzeller 1886).

\section{Onuphidae}

Hyalinoecia tubicola (O.F. Müller, 1776)

Material examined. Stns 834-99 (2), 848-99 (1).

\section{Nothria conchylega (M. Sars, 1835)}

Onuphis conchylega. - Hansen 1879b: 268. - von Marenzeller 1886: 21. - Fauvel 1913: 82. - Wesenberg-Lund 1950: 26.

Nothria conchylega. - Gulliksen 1974a: 23.

Material examined. Stns 2-72 (1), 808-99 (1), 834-99 (11).

Previous records. NNAE stn 223, 1 Aug. $1877,70^{\circ} 54^{\prime} \mathrm{N}$, $8^{\circ} 24^{\prime} \mathrm{W}, 128 \mathrm{~m}$ depth; NNAE stn 225, 2 Aug. 1877, $70^{\circ} 58^{\prime} \mathrm{N}, 8^{\circ} 4^{\prime} \mathrm{W}, 357 \mathrm{~m}$ depth (Hansen 1879b); Jan Mayen, 140-200 $\mathrm{m}$ depth (von Marenzeller 1886); RV Pourquoi-Pas? stn XX, 20 July 1912, 7050'N, 10³3’W, $180 \mathrm{~m}$ depth (Fauvel 1913); Ingolf stn 115, 23 July 1896, $70^{\circ} 50^{\prime} \mathrm{N}, 8^{\circ} 29^{\prime} \mathrm{W}, 162 \mathrm{~m}$; Ingolf stn 116, 23 July 1896, $70^{\circ} 05^{\prime} \mathrm{N}, 8^{\circ} 26^{\prime} \mathrm{W}, 699 \mathrm{~m}$ depth; RV Ryder, $70^{\circ} 32^{\prime} \mathrm{N}$, $8^{\circ} 10^{\prime} \mathrm{W}, 900 \mathrm{~m}$ depth; Søren Jensen, 25 June 1900, Jan Mayen, 100-110 m depth (Wesenberg-Lund 1950); stn 2-72 (1) Gulliksen (1974a).

\section{Lumbrineridae}

Abyssoninoe cf. abyssorum (McIntosh, 1885)

Material examined. Stn 803-99 (1).

Remarks. The material consists of one incomplete specimen, measuring $11 \mathrm{~mm}$ for 76 chaetigers, width $0.6 \mathrm{~mm}$ (without parapodia). The prostomium is conical, and is distinctly longer than wide (length/width ratio 1.4). Parapodia of the anterior body carry four limbate chaetae and two or three transitional chaetae, the transitional chaetae evolve from the shape of limbate chaetae at chaetiger two or three to ordinary hooded hooks at about chaetiger 12 or 13 . Dorsal capillary chaetae are present to chaetiger 64 . The specimen agrees with the description of Abyssoninoe abyssorum with regard to the size and distribution of chaetae (see, e.g., Orensanz 1990), but more material is needed to confirm the species affinity.

\section{Scoletoma fragilis (O.F. Müller, 1776)}

Lumbriconereis fragilis. - Fauvel 1913: 82. - WesenbergLund 1950: 27.

Lumbrinereis fragilis. - Hansen 1879b: 268. - von Marenzeller 1886: 21. - Gulliksen 1974a: 23.
Material examined. Stns 17-72 (1), 23-72 (2), 806-99 (8), 808-99 (4), 809-99 (1), 819-99 (1); 849-99 (3).

Previous records. NNAE stn 223, l Aug. 1877, $70^{\circ} 54^{\prime} \mathrm{N}$, $8^{\circ} 24^{\prime} \mathrm{W}, 128 \mathrm{~m}$ depth; NNAE stn 224, l Aug. 1877, $70^{\circ} 51^{\prime} \mathrm{N}, 8^{\circ} 20^{\prime} \mathrm{W}, 174 \mathrm{~m}$ depth; NNAE stn 225, 2 Aug. $1877,70^{\circ} 58^{\prime} \mathrm{N}, 8^{\circ} 4^{\prime} \mathrm{W}, 357 \mathrm{~m}$ depth (Hansen 1879b); Jan Mayen, $20 \mathrm{~m}$ depth (von Marenzeller 1886); RV Pourquoi-Pas? stn XX, 20 July 1912, 7050’ N, 10³3’W, $180 \mathrm{~m}$ depth (Fauvel 1913); Ingolf stn 115, 23 July 1896, $70^{\circ} 50^{\prime} \mathrm{N}, 8^{\circ} 29^{\prime} \mathrm{W}, 162 \mathrm{~m}$ depth (Wesenberg-Lund 1950); Stns 17-72 (1), 23-72 (2), 39 (1) Gulliksen (1974a).

Remarks. The specimens agree with the description given by Frame (1992). Most present specimens were $1.5-3.0 \mathrm{~mm}$ wide, measured at chaetiger 10. Single simple hooded hooks appear from chaetiger 12 to chaetiger 20, inserted between superior and inferior limbate chaetae. Maxillae III are provided with one strong blunt tooth. Maxillae IV are somewhat variable in shape, and in some specimens appear triangular in shape, in contrast to the "riding-hat" shape described by Frame (1992).

\section{*Scoletoma impatiens (Claparède, 1868)}

Lumbriconeris impatiens. - Wesenberg-Lund 1950: 27-28.

Previous reports. Ingolf stn 115, 23 July 1896, 70 $50^{\prime} \mathrm{N}$, $8^{\circ} 29^{\prime}$ W, 162 m depth (Wesenberg-Lund 1950).

Remarks: This must be considered a dubious record. This species is a temperate water species that, according to recent studies, does not occur in the northern North Atlantic (Oug, pers. obs.).

\section{Dorvilleidae}

Ophryotrocha littoralis (Levinsen, 1879)

Paractius littoralis. - von Marenzeller 1886: 21.

Paracticus littoralis. - Wesenberg-Lund 1953: 54.

Previous reports. Jan Mayen, 230-400 m depth (von Marenzeller 1886).

\section{Ophryotrocha sp. A}

Material examined. Stn 822-99 (1).

Remarks. The material consists of one complete specimen, measuring $4.5 \mathrm{~mm}$ for 57 chaetigers, width $0.45 \mathrm{~mm}$ (without parapodia). The prostomium carries small papilliform palps and antennae. The parapodia are without dorsal and ventral cirri. The maxillae are of the p-type, with forceps and 12-15 teeth, and a strong fang. The mandibles have two serrated teeth. The specimen differs from all known small species of Ophryotrocha from North Atlantic waters by the high number of chaetigers (see George \& Hartmann-Schröder 1985). In other respects it resembles Ophryotrocha gracilis Huth, 1933, by the presence of both antennae and palps, by the lack of parapodial cirri and by having bidentate mandibles. 
Parougia nigridentata (Oug, 1978)

Material examined. Stns 806-99 (1), 808-99 (5).

\section{Orbiniidae}

Naineris quadricuspida (Fabricius, 1780)

Naidonereis quadricuspida. - von Marenzeller 1886: 22.

Naineris quadricuspida. - Gulliksen et al. 1980: 140.

Previous reports. Jan Mayen, 20 m depth (von Marenzeller 1886); northern part of Jan Mayen, 5-30 m depth (Gulliksen et al. 1980).

\section{Scoloplos armiger (O. F. Müller, 1776)}

Scoloplos armiger. - von Marenzeller 1886: 22. Wesenberg-Lund 1953: 54. - Gulliksen et al. 1980: 140. Solbakken 2002: 34, 42-44.

Material examined. Stn 806-99 (25).

Previous records. Jan Mayen (von Marenzeller 1886); northern part of Jan Mayen, 5-30 m (Gulliksen et al. 1980); stn 806-99 (Solbakken 2002).

Remarks. Scoloplos armiger appears to have been confused with several closely related species in North Atlantic waters (Žadan 1998; Oug 2000; Solbakken 2002). The present specimens were compared with specimens from the North Sea and coastal Norwegian waters, and were found to agree in critical features such as neuropodial thoracic hooks, subpodal papillae and rose bengal staining patterns (Solbakken 2002). Wesenberg-Lund (1953) reported Scoloplos armiger from Jan Mayen by treating Aricia arctica Hansen, 1879 as a synonym. The latter species is considered here as valid (see below).

\section{Scoloplos arctica (Hansen, 1879)}

Aricia arctica Hansen, 1879b: 269, table II, figs. 1-8.

Scoloplos sp. A. - Solbakken 2002: 39-40, 44.

Material examined. Stns 806-99 (7), 822-99 (65).

Previous records. NNAE stn 224, l Aug. 1877, $70^{\circ} 51^{\prime} \mathrm{N}$, $8^{\circ} 20^{\prime} \mathrm{W}, 174 \mathrm{~m}$ depth; Jan Mayen, 18-27 $\mathrm{m}$ depth (Hansen 1879b).

Remarks. The specimens are similar to Scoloplos armiger in most respects, but differ by not having subpodal papillae, and by showing a different staining pattern when stained with rose bengal. Furthermore, the subpodal flanges are less well developed and flange papillae are lacking (Solbakken 2002). The present specimens were compared with Hansen's original material, which confirmed their similarity. Aricia arctica Hansen, 1879 has been synonymized with Scoloplos armiger in the literature (see, e.g., Wesenberg-Lund 1953), but is recognized here as a separate species. Žadan (1998) reported Scoloplos acutus from the north-east Atlantic. Scoloplos arctica differs from present descriptions of Scoloplos acutus (Pettibone
1963; Žadan 1998) by larger size, more thoracic setigers and the presence of numerous thoracic neuropodial hooks.

\section{Spionidae}

Polydora caulleryi Mesnil, 1897

Material examined. Stn 822-99 (1).

Remarks. The single specimen agrees with descriptions given by Kirkegaard (1996) and Hartmann-Schröder (1996).

\section{*Polydora caeca (Ørsted, 1843)}

Polydora coeca. - Wesenberg-Lund 1953: 59.

Previous reports. Wesenberg-Lund (1953).

Remarks. Wesenberg-Lund (1953) reported Polydora coeca from Jan Mayen with reference to Möbius (1874) and his species Leipoceras uviferum. This record cannot be confirmed from the original description, however, as there are no references to Jan Mayen (Möbius 1874).

Polydora socialis (Schmarda, 1861)

Material examined. Stn 806-99 (1).

Remarks. The specimen agrees with the description given by Hartmann-Schröder (1996).

\section{Prionospio cirrifera Wirén, 1883}

Prionospio cirrifera. - Söderström 1920: 237-238, fig. 146. Material examined. Stns 808-99 (5), 813-99 (4), 834-99 (11), 850-99 (1), unknown (2).

Previous records. $71^{\circ} 12^{\prime} \mathrm{N}, 8^{\circ} 28^{\prime} \mathrm{W}, 1275 \mathrm{~m}$ depth (Söderström 1920).

Remarks. The present material agrees well with the description given by Mackie (1984), who also examined the specimens reported by Söderström (1920) from Jan Mayen. The presence or absence of lateral pouches and their distribution are consistent with remarks by Sigvaldadottír (2002).

\section{Pygospio elegans Claparède, 1863}

Material examined. Stn 808-99 (6).

Remarks. All specimens were small, measuring up to 4-5 $\mathrm{mm}$ in length.

\section{Spio sp.}

Material examined. Stns 806-99 (1), 822-99 (1). Remarks. Two small and incomplete specimens were not possible to identify to species level.

Spio cf. filicornis (O.F. Müller, 1776)

Spio filicornis. - Gulliksen 1974a: 23. - Gulliksen et al. 1980: 140 .

Material examined. Stns 13B-72 (23), 806-99 (1). 
Previous records. Stn 13B-72 (Gulliksen 1974a); northern part of Jan Mayen, 5-30 m depth (Gulliksen et al. 1980).

Remarks. The specimens agree with present descriptions of Spio filicornis (Maciolek 1990; Worsaae 1999), by having well developed gills on chaetiger 1 and bidentate neuropodial hooded hooks starting on chaetiger 11 . There is, however, no pigmentation in the anterior body, which is distinctive for this species (Maciolek 1990). Presumably at least two species are confused under the name Spio filicornis in northern waters (Oug 2000).

\section{Spio goniocephala Thulin, 1957}

Material examined. Stn 822-99 (10).

Remarks. Specimens agree with the original description of Spio goniocephala (Thulin 1957), and with the characters given by Maciolek (1990). The prostomium is slightly prolonged, there are relatively well-devoloped gills on chaetiger 1 and bidentate hooded hooks commencing on chaetiger 16-18. These specimens resemble specimens reported as Spio armata from northern Norway (Oug 2000), but differ by having larger gills on chaetiger 1. On the anterior body there are brownish pigment spots on the prostomium, peristomium, and between the notopodia and the neuropodia.

\section{Spiophanes kroeyeri Grube, 1860}

Spiophanes kroeyeri. - Söderström 1920: 240-243, text figs. 150-152.

Material examined. Stn 834-99 (1).

Previous records. $71^{\circ} 12^{\prime} \mathrm{N}, 8^{\circ} 28^{\prime} \mathrm{W}, 1275 \mathrm{~m}$ depth (Söderström 1920).

Laonice cirrata (M. Sars, 1851)

Laonice cirrata. - Söderström 1920: 220-223, text fig. 128. Previous records. $71^{\circ} 12^{\prime} \mathrm{N}, 8^{\circ} 28^{\prime} \mathrm{W}, 1275 \mathrm{~m}$ depth (Söderström 1920).

\section{Poecilochaetidae}

Poecilochaetus serpens Allen, 1904

Material examined. Stn 848-99 (1).

\section{Paraonidae}

Aricidea quadrilobata Webster \& Benedict, 1887

Material examined. Stn 808-99 (1).

\section{Aricidea suecica Eliason, 1920}

Aricidea suecica. - Wesenberg-Lund 1950: 32-33.

Material examined. Stn 808-99 (1).

Previous records. Ingolf stn 116, 23 July 1896, $70^{\circ} 05^{\prime} \mathrm{N}$, $8^{\circ} 26^{\prime} \mathrm{W}, 699 \mathrm{~m}$ depth (Wesenberg-Lund 1950).
Levinsenia gracilis (Tauber, 1920)

Material examined. Stns 808-99 (57), 822-99 (1).

Paradoneis eliasoni Mackie, 1991

Material examined. Stn 848-99 (3).

\section{Paradoneis sp.}

Material examined. Stns 822-99 (3), 850-99 (1).

Remarks. The specimens are small and fragile. The branchiae appear on the fifth chaetiger and continue till the 9-1 1th chaetiger (between five and seven pairs of branchiae); notopodial postchaetal lobe is short and rounded (button-shaped). These specimens do not agree with descriptions of species belonging to the genus Paradoneis known from Arctic waters.

\section{Cirratulidae}

\section{Chaetozone christiei Chambers, 2000}

Material examined. Stns 806-99 (559), 808-99 (2), 822-99 (7).

Remarks. Specimens clearly differ from Chaetozone setosa, in lacking the characteristic long, fine capillary chaetae. Thoracic chaetae are short and arranged in prominent tufts, "bushiest" around the mid-thorax. The intersegmental furrows in posterior abdominal segments were not particularly marked, and the stout unidentate spines were present only laterally, i.e., not forming rings. The palps also clearly originated from a posterior position on the last achaetigerous peristomial segment. Specimens measure generally between $10-12 \mathrm{~mm}$ long and $1-1.5 \mathrm{~mm}$ wide for $85-89$ chaetigers, which is within the range reported by Chambers (2000). Specimens from station 822-99 were markedly larger in size, up to $24 \mathrm{~mm}$ in length and $1.5 \mathrm{~mm}$ wide, for 105 chaetigers, with very indistinct segmentation, and preserved specimens were dark reddish-brown in colour.

\section{Chaetozone setosa Malmgren, 1867}

Material examined. Stns 806-99 (69), 808-99 (255), 822-99(1), 848-99 (1).

Remarks. Specimens conformed well to the re-description of the taxon (Chambers 2000), and were easily recognized by the presence of very long, pale "silky" capillary chaetae along the thorax, especially in the posterior part, and the arrangement of the stout abdominal unidentate spines in almost complete rings in the posterior part of the abdomen. Pronounced intersegmental furrows in posterior abdominal segments ("concertina-like"). Also characteristic is the anterior origin of the palps on the last achaetous peristomial segment. The specimens also agree well with material found in the Norwegian Sea and northern North Sea 
(Cochrane \& Oug, pers. obs.). Specimens measure generally $15-23 \mathrm{~mm}$ long, and $1-1.5 \mathrm{~mm}$ wide, for $75-86$ chaetigers.

\section{Chaetozone sp. $\mathrm{C}$}

Material examined. Stns 806-99 (4), 808-99 (3), 808-99 (2).

Remarks. The prostomium is narrow and pointed, typical for Chaetozone, but the general body form is more reminiscent of Tharyx. It is narrowest in the mid-body segments, becoming wider and somewhat flattened in the posterior abdomen, and tapering to a narrow conical pygidium. The specimens tended to coil upon fixation. Prominent tufts of relatively long and fine capillary chaetae in posterior segments were present, almost reminiscent of Aphelochaeta, but the posterior three or four segments contain approximately between one and three very short unidentate spines. Several undescribed species in the North Atlantic have been reported (Chambers $\delta$ Woodham 2003).

Cirratulus cirratus (O. F. Müller, 1776)

Cirratulus cirratus. - Gulliksen et al. 1980: 140.

Previous reports. Northern part of Jan Mayen, 5-30 m depth (Gulliksen et al. 1980).

\section{Acrocirridae}

Macrochaeta polyonyx Eliason, 1962

Material examined. Stns 813-99 (3), 834-99 (1), 848-99 (79), 850-99 (1).

Remarks. All specimens are incomplete. The species is particularly characterized by the number of ventral compound hooks.

\section{Flabelligeridae}

Brada villosa (Rathke, 1843)

Brada villosa. - Wesenberg-Lund 1953: 67.

Previous reports. Jan Mayen (Wesenberg-Lund 1953).

\section{Flabelligera affinis M. Sars, 1829}

Flabelligera affinis. - Gulliksen et al. 1980: 140.

Previous reports. Northern part of Jan Mayen, 5-30 m depth (Gulliksen et al. 1980).

\section{Opheliidae}

Ophelina cylindricaudata (Hansen, 1879)

Ammotrypane cylindricaudatus. - Wesenberg-Lund 1950: 38. - 1953: 73 .

Material examined. Stn 808-99 (15); 848-99 (1).
Previous records. Ingolf stn 1 15, 23 July 1896, 70 ${ }^{\circ} 0^{\prime} \mathrm{N}$, $8^{\circ} 29^{\prime} \mathrm{W}, 162 \mathrm{~m}$ depth (Wesenberg-Lund 1950).

\section{Travisia forbesii Johnston, 1840}

Travisia forbesii. - Hansen 1879b: 270. - von Marenzeller 1886: 22. - Støp-Bowitz 1945a: 26-32, fig. 1. - Fauvel 1946: 401. - Gulliksen 1974a: 23.

Material examined. Stns 7-72 (2), 21 -72 (2), 29-72 (1), 806-99 (4), 822-99 (21).

Previous records. Jan Mayen, 18-27 m depth (Hansen 1879b); Jan Mayen, 20-30 m depth (von Marenzeller 1886); 12-22 June 1899, $70^{\circ} 55^{\prime} \mathrm{N}, 8^{\circ} 30^{\prime} \mathrm{W}, 14-36 \mathrm{~m}$ depth; 14 August 1930, 7051’N, 9²’W, 37-65 m depth; Mary Muss Bay, $23 \mathrm{~m}$ depth (Støp-Bowitz 1945a); RV Pourquoi-Pas? 1929 stn VIII, Jan Mayen (Fauvel 1946); Stns 7-72 (2), 21-72 (2), 29-72 (1) (Gulliksen 1974a).

\section{Scalibregmatidae}

\section{Pseudoscalibregma parvum (Hansen, 1879)}

Scalibregma parvum Hansen, 1879a: 7-8, table V, figs. 7-14. Pseudoscalibregma longisetosum. - Furreg 1925: 170-176, figs. S-X. - Wesenberg-Lund 1953: 70.

Pseudoscalibregma parvum. - Støp-Bowitz 1945b: 72-75, fig. 3.

Material examined. Stns 808-99 (1), 813-99 (22), 834-99 (26), 834-99 (76), 848-99 (7), 850-99 (4).

Previous records. $71^{\circ} 12^{\prime} \mathrm{N}, 8^{\circ} 28^{\prime} \mathrm{W}, 1275 \mathrm{~m}$ depth (Støp-Bowitz 1945b); $71^{\circ} 05^{\prime} \mathrm{N}, 8^{\circ} 5 \mathrm{l}^{\prime} \mathrm{W}, 800 \mathrm{~m}$ depth (Furreg 1925).

Remarks. Most specimens are complete, measuring 9-12 $\mathrm{mm}$ for 30-32 chaetigers. The body is elongate, with a more or less strongly swollen part from chaetiger 5 to chaetigers 11 or 12 . The parapodia are knoblike in the anterior body, and well developed in the posterior body behind the swollen area. Parapodia are supplied with capillary chaetae and dense tufts of lyrate chaetae in both rami. Støp-Bowitz (1945b) confirmed that Scalibregma parvum Hansen, 1879 and Eumenia longisetosa Théel, 1879 (= Pseudoscalibregma longisetosum) are synonymous, and pointed out that Hansen's name was published first, and takes priority.

\section{Scalibregma inflatum Rathke, 1843}

Scalibregma inflatum. - Furreg 1925: 157-163. - StøpBowitz 1945b: 67-72, fig. 2.

Material examined. Stns 808-99 (17), 813-99 (1).

Previous records. 24 June $1899,71^{\circ} 12^{\prime} \mathrm{N}, 8^{\circ} 28^{\prime} \mathrm{W}$, $1275 \mathrm{~m}$ depth (Furreg 1925).

\section{Capitellidae}

Capitella sp. A

Material examined. Stns 806-99 (120), 822-99 (84). 
Remarks. The specimens have six anterior chaetigers with pale capillary chaetae in slender bundles, sometimes also with a few capillary chaetae mixed with the hooks on the seventh notopodia. All specimens with at least one pair of genital hooks on the dorsum of chaetigers 8 or 9 , pale yellow in colour, often difficult to observe. As such, the specimens conform to the description of Capitella giardi (Mesnil, 1897), which has mixed chaetae on chaetiger 7 (Warren 1991), and was previously recorded from the North Atlantic (reviewed in Hartmann-Schröder 1996). However, eyes were observed on most of the specimens, which are reputed to be absent in adult Capitella giardi. Specimens of up to $14 \mathrm{~mm}$ in length, for approximately 50 segments, were recorded. Oug (2000) noted similar specimens near Tromsø, northern Norway, albeit with fully seven anterior chaetigers with capillary chaetae, and reported these as Capitella sp. We do not have the opportunity to compare the Jan Mayen material with certified specimens of Capitella giardi and related taxa, so the specimens are simply referred to as Capitella sp. A.

\section{Capitella sp. B}

Material examined. Stn 822-99 (52).

Remarks. All specimens clearly with seven anterior chaetigers, they are generally stouter and larger than Capitella sp. A. Chaetal bundles are generally more prominent than those observed in Capitella sp. A. All specimens bear genital hooks. Some individuals with dark, ambercoloured capillary chaetae; others with pale, almost transparent chaetae. One brooding female was observed in a tube made of brittle transparent mucus, with large adhering sand grains. Future studies should investigate whether Capitella sp. A and B are juvenile and adult forms, respectively.

Capitella capitata (O. Fabricius, 1780)

Capitella capitata. - Gulliksen et al. 1980: 140.

Previous reports. Northern part of Jan Mayen, 5-30 m depth (Gulliksen et al. 1980).

Remarks. Capitella capitata is one of the most widely recorded polychaetes worldwide, and numerous recent studies show it is also one of the most misidentified taxa. This record should be treated with caution until the specimen can be re-examined to confirm its identity.

\section{Heteromastus filiformis Claparède, 1864}

Material examined. Stns 806-99 (3), 808-99 (13), 822-99 (13).

Remarks. All specimens observed with five segments with capillary chaetae, followed by five segments bearing only hooks. Specimens from station 808-99 are consistently smaller than those from station 806-99, almost reminiscent of Mediomastus from more southern locations such as the UK (Cochrane, pers. obs.), but definitely bearing five sets of capillary chaetae. Characteristic anal cirrus is observed on specimens from station 808-99; posterior segments are missing from specimens from station 806-99.

Notomastus latericeus M. Sars, 1851

Material examined. Stn 808-99 (3).

Remarks. The specimen is missing posterior segments. The thorax bears one anterior achaetous and 11 chaetigerous segments. The thorax has a characteristic rugose appearance.

\section{Maldanidae}

\section{Praxillura longissima Arwidsson, 1907}

Praxillura longissima. - Arwidsson 1907: 27-32, table 1, figs. 1-7, table 7, figs. 208, 212, 214, $215,218$.

Previous reports. Hvalrossbukt, $70^{\circ} 58^{\prime} \mathrm{N}, 8^{\circ} 42^{\prime} \mathrm{W}, 36 \mathrm{~m}$ depth; $71^{\circ} 50^{\prime} \mathrm{N}, 8^{\circ} 51^{\prime} \mathrm{W}, 800 \mathrm{~m}$ depth (Arwidsson 1907).

Nicomache lumbricalis (O. Fabricius, 1780)

Nicomache lumbricalis. - von Marenzeller 1886: 22. Fauvel 1913: 89-90. - 1946: 401.

Previous reports. Jan Mayen (von Marenzeller 1886); RV Pourquoi-Pas? stn XX, 20 July 1912, 7050’ N, 10³3’W, 180 m depth (Fauvel 1913); RV Pourquoi-Pas? stn V, Jan Mayen (1929) (Fauvel 1946).

Nicomache quadrispinata Arwidsson, 1907

Material examined. Stn 850-99 (1).

Remarks. A small anterior fragment with six setigerous segments is present. The distribution of glands and the presence of a single, straight acicular spine per torus in the first four chaetigers are characteristic for the species.

Clymenura polaris (Théel, 1879)

Leiochone polaris. - Arwidsson 1907: 150-156, table 4, figs 1 18-128, table 9, figs 284-287.

Previous reports. $70^{\circ} 55^{\prime} \mathrm{N}, 8^{\circ} 30^{\prime} \mathrm{W}, 14-21 \mathrm{~m}$ depth (Arwidsson 1907).

\section{Macroclymene sp. A}

Material examined. Stn 808-99 (2).

Remarks. One complete specimen and one anterior fragment are present. The complete specimen is about $17 \mathrm{~mm}$ long for 33 or 34 chaetigers and one achaetous pre-anal segment (the number of segments is difficult to count precisely because of the regeneration of the posterior part). The anterior fragment is $9 \mathrm{~mm}$ long with $18 \mathrm{cha}$ etigers. The specimens are referred to the genus Macroclymene Verrill, 1900 inter alia based on the presence 
of a cephalic plate with a rim, a relatively high number of chaetigerous segments and the presence of a pygidial funnel rimmed with several (>10) cirri. (Wolf 1984). The specimens probably belong to an undescribed species.

\section{Microclymene sp. A}

Material examined. Stn 808-99 (2).

Remarks. Two anterior fragments are present. The largest is $20 \mathrm{~mm}$ long for 28 chaetigers, with the head and first two chaetigers regenerating. The second specimen is $11 \mathrm{~mm}$ long for 10 chaetigers. The specimens agree well with specimens from Iceland (BIOICE collection, several complete specimens) identified to the same taxon (Kongsrud, pers. obs.). The general form of the pygidium, with a short caudal cirrus extending along the ventral side of the anal cone, indicates a close relationship with Microclymene caudata Imajima \& Shiraki, 1982 from Japan. However, the specimens identified as Microclymene sp. A is believed to represent an undescribed species.

Praxillella gracilis (M. Sars, 1861)

Material examined. Stn 808-99 (4).

\section{Praxillella praetermissa minor Arwidsson, 1907}

Praxillella praetermissa var. minor. - Arwidsson 1907: 204205, table 4, fig. 144.

Material examined. Stns 806-99 (34), 808-99 (1). Previous reports. Mary Muss Bay, $71^{\circ} 00^{\prime} \mathrm{N}, 8^{\circ} 30^{\prime} \mathrm{W}$, $23 \mathrm{~m}$ depth; Treibholz Bay, $70^{\circ} 55^{\prime} \mathrm{N}, 8^{\circ} 30^{\prime} \mathrm{W}, 14-21 \mathrm{~m}$ depth (Arwidsson 1907).

Remarks. Arwidsson (1907) described this taxon based on two specimens from Jan Mayen. In the present material there are 22 complete specimens and several anterior and posterior fragments. There seems to be no other records of this taxon in the literature, and the validity has been questioned (Banse 1981). The main character separating it from the nominal species Praxillella praetermissa (Malmgren, 1866), is the presence of a glandular band in front of the parapodium on the ninth chaetiger. This band is present on all the examined specimens, and the typical Praxillella praetermissa is not known from Jan Mayen.

\section{Maldane sarsi Malmgren, 1866}

Maldane sarsi. - Arwidsson 1907: 251-261, table 6, figs. 192-199, table 10, figs. 333-338.

Previous reports. $71^{\circ} 50^{\prime} \mathrm{N}, 8^{\circ} 51^{\prime} \mathrm{W}, 800 \mathrm{~m}$ depth (Arwidsson 1907).

Notoproctus oculatus arctica Arwidsson, 1907

Material examined. Stn 848-99 (1).

Remarks: A small complete specimen, about $6 \mathrm{~mm}$ long for 17 chaetigers and three achaetous pre-anal segments.

\section{Rhodine gracilior Tauber, 1879}

Material examined. Stn 808-99 (6).

Remarks: The specimens of Rhodine are extremely fragile, and only anterior fragments are present in the sample. The distribution of glands on the anterior chaetigers and shape of the collar on chaetigers 2 and 3 agrees well with the description of Rhodine gracilior by Arwidsson (1907).

\section{Oweniidae}

Galathowenia oculata (Zaks, 1923)

Myriochele sp. - Gulliksen 1974a: 23.

Material examined. Stns 9-72 (1), 22-72 (1), 23-72 (3), 37-72 (1), 38-72 (2), 39-72 (1), 808-99 (>100), 817-99 (1).

Previous records. Stns 9-72, 22-72, 23-72, 37-72, 38-72, 39-72 (Gulliksen 1974a).

Remarks. Nilsen \& Holthe (1985) mentioned characteristic eye spots as a character for identification of this species. Although eye spots and pigmentation have not been reported to be present in different populations (Nilsen \& Holthe 1985; Parapar 2003), pigmented eye spots were observed in all samples from Jan Mayen. Pigmentation on the collar was variable, with some pigment spots in some specimens, and with pigments spots absent in others.

\section{Owenia assimilis (Sars, 1851)}

Ammochares assimilis. - Hansen 1879b: 270.

Owenia assimilis. - Koh, Bhaud \& Jirkov 2003: 182-183.

Previous reports. NNAE stn $224,70^{\circ} 50^{\prime} \mathrm{N}, 8^{\circ} 20^{\prime} \mathrm{W}$, $174 \mathrm{~m}$ depth (Hansen 1879b).

Remarks. This species was originally treated as synonymous with Owenia fusiformis, e.g., by Fauvel (1927), a synonymy that has been accepted by most authors since. Koh et al. (2003), however, re-established the species, but advised that more material should be examined for a re-description and clarification of the characters. Koh et al. (2003) indicated records from Jan Mayen, but referred incorrectly to Malmgren (1867) and Sars (1851) as sources, rather than Hansen (1879b). The identity of the species needs to be confirmed, considering that several similar species may occur in the area (see Koh et al. 2003).

\section{*Owenia fusiformis delle Chiaje, 1841}

Owenia fusiformis. - Wesenberg-Lund 1950: 45-46. 1953: 87. - Nilsen \& Holthe 1985: 19.

Previous reports. Ingolf stn 115, 23 July 1896, 7050’ N, $8^{\circ} 29^{\prime}$ W, 162 m depth (Wesenberg-Lund 1950).

Remarks: Owenia fusiformis does not occur in the North Atlantic (Koh et al. 2003). Specimens identified by Wesenberg-Lund (1950) from Jan Mayen need to be 
re-examined to confirm their identity. Wesenberg-Lund (1953) and Nilsen \& Holthe (1985) reported Owenia fusiformis from Jan Mayen based on the record of Ammochares assimilis by Hansen (1879b).

Owenia polaris Koh, Bhaud \& Jirkov, 2003

Owenia fusiformis. - Gulliksen 1974a: 23.

Material examined. Stns 7-72 (4), 21 -72 (3), 38-72 (1), 806-99 (1), 808-99 (11).

Previous records. Stns 7-72, 21-72, 38-72 (Gulliksen 1974a) as Owenia fusiformis.

Remarks. Specimens identified as Owenia fusiformis from the 1972 survey (Gulliksen 1974a) were re-identified to Owenia polaris, based on the recent description by Koh et al. (2003). The specimens conform well to their description: the angle of teeth of the uncini relative to the front shaft, no shoulder present, the tentacular crown being short in all specimens in a $1: 2$ tentacular crown: thorax length ratio (Koh et al. 2003). Hence, these specimens differ from the Owenia fusiformis described from the Mediterranean (Koh et al. 2003) by the length of the tentacular crown, and also by the angle of teeth of the uncini. As previously reported for Owenia fusiformis from the same area (Nilsen \& Holthe 1985), the examined specimens were pigmented on the collar and thoracic segments, although pigmentation patterns varied from a few small spots to larger dorsal and lateral areas. Specimens measured up to $40 \mathrm{~mm}$ in length. The variation of these few specimens compared with the few studied by Koh et al. (2003) indicate a larger variation that should be taken into account when more material is available. The bottom temperature at the sampling locality was measured to $1.5^{\circ} \mathrm{C}$ at the time of sampling (Lønne 1999), which is consistent with that reported by Koh et al. (2003).

\section{Ampharetidae}

Ampharete acutifrons (Grube, 1860)

Ampharete acutifrons. - Wesenberg-Lund 1950: 47.

Previous reports. Ingolf stn 115, 23 July 1896, 7050' $\mathrm{N}$, $8^{\circ} 29^{\prime} \mathrm{W}, 162 \mathrm{~m}$ depth (Wesenberg-Lund 1950).

\section{Ampharete baltica Eliason, 1955}

Ampharete baltica. - Gulliksen 1974a: 23. - Holthe 1986: 34-35, fig. 9, map 8.

Material examined. Stn 7-72 (1).

Previous records. Stn 7-72 (Gulliksen 1974a).

\section{Ampharete finmarchica (M. Sars, 1866)}

Ampharete finmarchica. - Gulliksen 1974a: 23. - Holthe 1986: 38-39, fig. 11, map 10.

Previous records. Stns 3-72, 9-72, 17-72, 23-72, 29-72, 39-72 (Gulliksen 1974a).
Amphicteis gunneri (M. Sars, 1835)

Amphicteis gunneri. - Wesenberg-Lund 1950: 47-48.

Previous reports. Ingolf stn 115, 23 July 1896, 7050'N, $8^{\circ} 29^{\prime} \mathrm{W}, 162 \mathrm{~m}$ depth (Wesenberg-Lund 1950).

\section{Anobothrus gracilis (Malmgren, 1866)}

Anobothrus gracilis. - Holthe 1986: 50-51, fig. 18, map 17.

Previous reports. Jan Mayen (Holthe 1986).

\section{Eclysippe vanelli (Fauvel, 1936)}

Materiel examined. Stns 834-99 (2), 848-99 (12).

Remarks. Specimens agree with description given by Holthe (1986). Holthe reported this species from the Norwegian coast at 15-313 m depth. This depth range is increased here by the specimens found in this study, from stations 834 and 848 at depths of 771 and $599 \mathrm{~m}$, respectively.

\section{Glyphanostomum pallescens (Théel, 1879)}

Glyphanostomum pallescens. - Holthe 1986: 70-73, fig. 29, map 28.

Material examined. Stn 813-99 (1).

Previous records. Holthe (1986) referred to previous records of this species from Jan Mayen, but the original references have not been traced.

\section{Melinna cristata (M. Sars, 1851)}

Melinna cristata. - Holthe 1986: 81-83, fig. 34, map 33.

Previous reports. Ingolf stn 115, 23 July 1896, 7050’ N, $8^{\circ} 29^{\prime} \mathrm{W}, 162 \mathrm{~m}$ depth (Wesenberg-Lund 1950); Jan Mayen (Holthe 1986).

Remarks. The specimens reported from Jan Mayen by Holthe (1986) were most likely the same material identified by Wesenberg-Lund (1950). Melinna cristata as used in the literature has recently been shown to be a species complex in North Atlantic waters representing the three species Melinna cristata, Melinna elisabethae and Melinna albicincta (Mackie \& Pleijel 1995). The material of Melinna cristata from Jan Mayen should be re-examined.

\section{Melinna elisabethae McIntosh, 1922}

Material examined. Stn 808-99 (2).

Remarks. Specimens agree with description given by Mackie \& Pleijel (1995).

Melythasides laubieri Desbruyeres, 1978

Material examined. Stn 848-99 (13).

\section{Terebellidae}

Baffinia hesslei (Annenkova, 1924)

Terebella hesslei. - Gulliksen 1980 et al.: 140.

Baffinia hesslei. - Holthe 1986: 94-95, fig. 39, map 38. 
Previous reports. Northern part of Jan Mayen, 5-30 m depth (Gulliksen et al. 1980); Jan Mayen (Holthe 1986).

Eupolymnia nesidensis (delle Chiaje, 1828)

Polymnia nesidensis. - Gulliksen 1974a: 24.

Eupolymnia nesidensis. - Holthe 1986: 111-112, fig. 48, map 47.

Material examined. Stn 11B-72 (1).

Previous records. Stn $11 \mathrm{~B}$ (Gulliksen 1974a); Jan Mayen (Holthe 1986).

Lanassa venusta (Malm, 1874)

Material examined. Stn 808-99 (7).

Laphania boecki Malmgren, 1866

Laphania boecki. - Gulliksen 1974a: 24. - Holthe 1986: 130-131, fig. 58, map 57.

Material examined. Stns 8-72 (1), 17-72 (3), 806-99 (1), 808-99 (19), 822-99 (23).

Previous records. Stns 8-72, 17-72 (Gulliksen 1974a); Jan Mayen (Holthe 1986).

\section{Neoamphitrite affinis (Malmgren, 1866)}

Amphitrite affinis. - von Marenzeller 1886: 22. Wesenberg-Lund 1953: 95.

Previous reports. Jan Mayen, $230 \mathrm{~m}$ depth (von Marenzeller 1886).

\section{Nicolea venustula (Montagu, 1818)}

Nicolea venustula. - von Marenzeller 1886: 22-23. Wesenberg-Lund 1950: 51-52.

Previous reports. Jan Mayen, 20 and $140 \mathrm{~m}$ depths (von Marenzeller 1886); Ingolf stn 116, 23 July 1896, $70^{\circ} 05^{\prime} \mathrm{N}, \quad 8^{\circ} 26^{\prime} \mathrm{W}, \quad 699 \mathrm{~m}$ depth (Wesenberg-Lund 1950).

\section{Nicolea zostericola (Ørsted, 1844)}

Nicolea zostericola. - Fauvel 1946: 402. - Gulliksen et al. 1980: 140. - Holthe 1986: 124-126, fig. 55.

Previous reports. RV Pourquoi-Pas? 1929 stn VII, Jan Mayen (Fauvel 1946); northern part of Jan Mayen, 5-30 m depth (Gulliksen et al. 1980); Jan Mayen (Holthe 1986).

Thelepus cincinnatus (O. Fabricius, 1780)

Thelepus cincinnatus. - von Marenzeller 1886: 23.

Previous reports. Jan Mayen, $230 \mathrm{~m}$ depth (von Marenzeller 1886).

Polycirrus arcticus M. Sars, 1865

Polycirrus albicans. - Wesenberg-Lund 1950: 55.

Previous reports. Ingolf stn 116, 23 July 1896, $70^{\circ} 05^{\prime} \mathrm{N}$, $8^{\circ} 26^{\prime} \mathrm{W}, 699 \mathrm{~m}$ depth (Wesenberg-Lund 1950).
Polycirrus medusa Grube, 1850

Ereutho smitti. - von Marenzeller 1886: 23.

Previous reports. Jan Mayen, 20-400 m depth (von Marenzeller 1886).

Polycirrus norvegicus (Wollebæk, 1912)

Polycirrus norvegicus. - Gulliksen et al. 1980: 140.- Holthe 1986: 157, fig. 72, map 71.

Previous reports. Northern part of Jan Mayen, 5-30 m depth (Gulliksen et al. 1980); Jan Mayen (Holthe 1986).

\section{Trichobranchidae}

Terebellides stroemi M. Sars, 1835

Terebellides stroemi. - Hansen 1879b: 271. - WesenbergLund 1950: 55-56. - Gulliksen 1974a: 23. - Holthe 1986: 170-172, fig. 80, map 79.

Material examined. Stn 23-72 (2).

Previous records. NNAE stn 225, 2 Aug. 1877, $70^{\circ} 58^{\prime} \mathrm{N}$, $8^{\circ} 4^{\prime} \mathrm{W}, 357 \mathrm{~m}$ depth (Hansen 1879b); Ingolf stn 115, 23 July $1896,70^{\circ} 50^{\prime} \mathrm{N}, 8^{\circ} 29^{\prime} \mathrm{W}, 162 \mathrm{~m}$ depth (WesenbergLund 1950); stn 23-72 (Gulliksen 1974a); Jan Mayen (Holthe 1986).

\section{Sabellidae}

Chone duneri Malmgren, 1867

Material examined. Stn 822-99 (1).

Remarks. Chone duneri was described from Svalbard. However, the abundant records of Chone duneri along the Norwegian coast and the northern North Sea very often refer to Chone longocirrata Langerhans, 1881 and at least one other undescribed taxon (discussed as Chone A in Cochrane 2000). The specimens have six pairs of flanged radioles, united by the inter-radiolar (palmate) membrane for approximately two-thirds of their length. The collar is ventrally intact, with an anteriorly rounded margin that bears an inverted horseshoe-shaped ciliated patch (remains uncoloured after staining with methyl green; also see comments in Banse 1970). It is distinguished from both Chone fauveli and Chone infundibuliformis by having fewer pairs of radioles, and from the former by the long free ends of the radioles. It is further distinguished from Chone longocirrata by having fully spatulate thoracic notochaetae (in inferior posterior position), rather than the narrower, "pseudospatulate" chaetal type.

Chone fauveli McIntosh, 1916

Chone infundibuliformis. - Gulliksen 1974a: 24.

Material examined. Stns 1 1-72 (30), 24-72 (16), 25-72

(83), 806-99 (1), 822-99 (145). 
Previous records. Stns 11-72, 24-72, 25-72 (Gulliksen 1974a, as Chone infundibuliformis).

Remarks. All specimens measure more than $80 \mathrm{~mm}$ in trunk length, some more than $120 \mathrm{~mm}$. Chone fauveli has until recently not been given much attention in the literature, such that it is often misidentified as Chone infundibuliformis. The most obvious feature is the prominent outward flare of the collar, which does not appear to be a preservation artefact (Knight-Jones, pers. com.). It is easily distinguished from Chone infundibuliformis by having more pairs of radioles (up to 36 pairs, compared with just over 20 pairs), with short, broad flanged tips, instead of long, tapering free ends. Chone fauveli completely lacks the characteristic apinnate ventral cirri (also called radiolar appendages), but does have distinctly elongated pinnules on the dorsalmost radioles (pinnular appendages). However, the radiolar lobes tend to curl inwards on fixation, such that the dorsal pinnular appendages are actually visible ventrally. This may cause the feature to be misinterpreted as apinnate ventral cirri, and consequently the specimens are misidentified. Specimens collected in 1972 were around half the size of those found in 1999. Chone fauveli is common in British waters (generally lesser body size), and is also recorded from northern Norway (Sars 1862), described as Chone fauvelii Sars (Knight-Jones, pers. com.; also discussed in Cochrane 2000).

\section{Chone infundibuliformis Krøyer, 1856}

Chone infundibuliformis. - von Marenzeller 1886: 23. Fauvel 1913: 91. - Wesenberg-Lund 1953: 108-109.

Previous reports. Jan Mayen, 20-240 m depth (von Marenzeller 1886); south coast of Jan Mayen RV Pourquoi-Pas? stn XXI, 21 July 1912, 7057'N, 10³9’W, $37 \mathrm{~m}$ depth (Fauvel 1913); Jan Mayen, $30 \mathrm{~m}$ depth (Wesenberg-Lund 1953).

Remarks. As a result of revisions and frequent misidentifications (see above for comments on Chone fauveli and Chone duneri), early references to Chone infundibuliformis should be re-examined to verify the true identity of the specimens. More specimens were reported in Gulliksen (1974a) than are included here. This material has not been possible to obtain, and may be lost.

\section{Chone paucibranchiata (Krøyer, 1856)}

Material examined. Stns 808-99 (198), 848-99 (1), 850-99 (1).

Remarks. Specimens characteristically with a trunk length of less than $10 \mathrm{~mm}$, approximately $1-1.5 \mathrm{~mm}$ wide. Three pairs of radioles only, with a low palmate membrane. The crown is typically detached from trunk on fixation. Dorsal collar margins are thin, membranous and often slightly bulged. Very characteristic is the pres- ence of prominent bilobed ventral extensions of the anterior peristomial ring, projecting beyond the anterior collar margins. The tube is made of thick parchment-like mucus, with adhering sand/mud particles. A further description is given in Banse (1970) and Cochrane (2000).

\section{Euchone analis (Krøyer, 1856)}

Euchone analis. - von Marenzeller 1886: 23. - WesenbergLund 1950: 59.

Material examined. Stn 822-99 (3).

Previous records. Jan Mayen, $30 \mathrm{~m}$ depth, (von Marenzeller 1886); Ingolf stn 115, 23 July 1896, 7050'N, $8^{\circ} 29^{\prime} \mathrm{W}, 162 \mathrm{~m}$ depth; Ingolf stn 116, 23 July 1896, $70^{\circ} 05^{\prime} \mathrm{N}, 8^{\circ} 26^{\prime} \mathrm{W}, 699 \mathrm{~m}$ depth (Wesenberg-Lund 1950). Remarks. Specimens conform to the description given in Banse (1970), with 10 pairs of flanged radioles and three or four pairs of ventral cirri (adjacent to the ventralmost radioli, lacking pinnules), and with the ventral pair being shortest. The free ends of the radioles are tapering. The palmate membrane extends approximately half the length of the crown. They are readily distinguished from Euchone elegans Verrill, 1873 by having a larger number of radioles and abdominal segments, as well as more tapering free ends of radioles. In addition, the abdominal uncini in Euchone analis are characteristically square or box-shaped, whereas those in Euchone elegans usually have a pronounced posterior extension.

\section{Laonome kroyeri Malmgren, 1865}

Material examined. Stn 806-99 (2).

Remarks. Laonome often superficially resembles large Chone, such as Chone fauveli in this study. However, it is easily distinguished by its lack of palmate membrane, and by both the thoracic and abdominal uncini having rounded breasts and lacking handles. Further information is given in Fitzhugh (1989).

\section{Bispira crassicornis (M. Sars, 1851)}

Sabella crassicornis. - von Marenzeller 1886: 23.

Material examined. Stn 834-99 (1).

Previous records. Jan Mayen, $130 \mathrm{~m}$ depth (von Marenzeller 1886).

Remarks. The previously large and complex group Sabella, together with Bispira and Stylomma, was relatively recently revised (Knight-Jones \& Perkins 1998). Sabella was restricted to include only species that have spiralled fascicles of abdominal chaetae, a straight anterior border of the first thoracic shield, and radioles that lack composite eyes and flanges. Most species formerly placed in Sabella, including Sabella crassicornis, were referred to Bispira. These have abdominal chaetal fascicles posessing C-shaped fascicles of abdominal chaetae, first thoracic 
shield with a W-shaped anterior border, and, in most species, radioles with paired composite eyes and flanges (Knight-Jones \& Perkins 1998). Spirality of the crown is not unique for the group Bispira, and not all of its members possess the feature. Bispira crassicornis was described from northern Norway, but has been misidentified from numerous localities, including the Mediterranean, Moroccan coast and the British Isles. The geographical distribution appears to be in deeper or cold waters of the northern Atlantic, extending across the Arctic Ocean to Alaska. In the far northern Atlantic/ Arctic, it is likely to be replaced by Bispira fabricii (see Knight-Jones \& Perkins 1998). Both Johansson (1927) and Fauvel (1927) erroneously synonymized Bispira crassicornis with Bispira fabricii. As a result, previous records of both taxa should be treated with some caution, or the specimens should be re-examined. Also see the remarks below for Bispira fabricii.

\section{*Bispira fabricii (Krøyer, 1856)}

Sabella fabricii. - Wesenberg-Lund 1953: 106.

Remarks. This taxon was originally described from Greenland as Sabella fabricii, and was referred to Bispira by Knight-Jones \& Perkins (1998; see remarks above), but has often been confused with Bispira crassicornis. Furthermore, Sabella spetsbergensis Malmgren, 1866 is referred to Bispira fabricii. Bispira crassicornis has longer ventral collar lappets and more numerous eyes on the radioles than Bispira fabricii (for a full description, see Knight-Jones $\delta$ Perkins 1998). The distribution appears to be confined to the Arctic waters of the North Atlantic. The record mentioned by Wesenberg-Lund (1953) is not a primary record, but a reference to von Marenzeller (1886), who referred to this species as Sabella crassicornis. Von Marenzeller (1886) listed this species as a synonym of Sabella crassicornis. As mentioned above, specimens should be re-examined to verify their true identity.

\section{Serpulidae}

\section{Apomatus similis Marion \& Bobretzky, 1875}

Material examined. Stn 817-99 (2).

Remarks. Both specimens are lacking an operculum. One has a regenerating branchial crown. The identification is based on the collar, thoracic neuropodia and presence of "Apomatus chaetae" on the fourth thoracic segment.

\section{Placostegus tridentatus (O. Fabricius, 1779)}

Placostegus tridentatus. - Wesenberg-Lund 1950: 60.

Previous reports. Ingolf stn 115, 23 July 1896, 7050'N, $8^{\circ} 29^{\prime} \mathrm{W}, 162 \mathrm{~m}$ depth (Wesenberg-Lund 1950).

Remarks. In her text, Wesenberg-Lund (1950) stated the depth to be $1802 \mathrm{~m}$, which contradicts the depth of
$162 \mathrm{~m}$ in the station list. It is assumed that the latter is the correct one, as $1802 \mathrm{~m}$ is the depth of the Ingolf station 104, where this species is also found.

\section{Serpulidae: Spirorbinae}

Remarks. Eleven specimens in tubes were found in the material collected in 1999, all lacking the anterior part of the body, possibly as a result of rough handling when parting the tubes from the substrate, and are therefore not identifiable. Of these, two tubes had wide prominent trumpet-shaped openings and transversal growth rings. The tubes were very delicate.

Circeis spirillum (L., 1758)

Spirorbis spirillum. - von Marenzeller 1886: 23. Wesenberg-Lund 1953: 116.

Previous reports. Jan Mayen (von Marenzeller 1886).

\section{Jugaria quadrangularis (Stimpson, 1854)}

Spirorbis sp. - Gulliksen 1974a: 24.

Material examined. Stn 2-72 (2).

Previous records. Stn 2-72 (Gulliksen 1974a).

Remarks. Two specimens are present, one partly in a tube, with an opercular brood chamber and a distinct angular hourglass-shaped talon. An additional five small specimens are present in the material, with no eggs in the operculum, but talons similar to the one referred to Jugaria quadrangularis by Knight-Jones et al. (1991: 194, fig. 4b).

\section{Jugaria granulata (L., 1767)}

Spirorbis granulatus. - Fauvel 1913: 82. - Wesenberg-Lund 1950: 63. - 1953: 118.

Previous reports. Jan Mayen RV Pourquoi-Pas? stn XX, 20 July 1912, 7050' N, 10³3'W, $180 \mathrm{~m}$ depth (Fauvel 1913); Ingolf stn 117, 24 July 1896, 69² $13^{\prime} \mathrm{N}, 8^{\circ} 23^{\prime} \mathrm{W}$, $1889 \mathrm{~m}$ depth (Wesenberg-Lund 1950).

\section{Spirorbis spirorbis (L., 1758)}

Spirorbis spirorbis. - Wesenberg-Lund 1950: 63.

Previous reports. Ingolf stn 115, 23 July 1896, 7050’ N, $8^{\circ} 29^{\prime}$ W, 162 m depth (Wesenberg-Lund 1950).

Remarks. This is a littoral or shallow sublittoral species living on large algae such as Fucus spp. (Knight-Jones \& Knight-Jones 1977). The report from Jan Mayen at a depth of $162 \mathrm{~m}$ by Wesenberg-Lund must be considered dubious, and the specimens should be re-examined.

\section{Acknowledgements}

The cruise in 1999 was organized by the University Centre in Svalbard as a part of a graduate course in Arctic 
benthic fauna (course AB301). We are grateful to Bjørn Gulliksen and Ole Jørgen Lønne who organized the 1999 cruise in which one of us (TB) participated, to fellow students for their help with sampling, to Jon-Arne Sneli and Torleiv Brattegard for help and advice during the cruise and to the crew of the RV Jan Mayen. We would like to thank the late Torleif Holthe for fruitful discussions on Arctic fauna and biogeography, and Ruth Barnich and Ole S. Tendal for help with information. This is a contribution from the Norwegian Polychaete Forum.

\section{References}

Arwidsson I. 1907. Studien über die skandinavischen und arktischen Maldaniden nebst Zusammenstellung der übrigen bisher bekannten Arten dieser Familie. (Studies of the Scandinavian and Arctic maldanids, with a compilation of the currently known species within this family.) Zoologische Jahrbücher, Abteilung für Systematik, Geographie und Biologie der Tiere 25, Supp. 9. Jena: Gustav Fischer.

Banse K. 1970. The small species of Euchone Malmgren (Sabellidae, Polychaeta). Proceedings of the Biological Society of Washington 83, 387-408.

Banse K. 1981. On some Cossuridae and Maldanidae (Polychaeta) from Washington and British Columbia. Canadian Journal of Fisheries and Aquatic Sciences 38, 633-637.

Blindheim J. 2004. Oceanography and climate. In H.R. Skjoldal (ed.): The Norwegian Sea ecosystem. Pp. 65-96. Trondheim: Tapir Academic Press.

Brattegard T. \& Fosså J.H. 1991. Replicability of an epibenthic sampler. Journal of the Marine Biological Association of the UK 71, 153-166.

Brattegard T. \& Holthe T. (eds.) 1997. Distribution of marine, benthic macro-organisms in Norway. Research Report for DN 1997-1. Trondheim: Directorate for Nature Management.

Chambers S. 2000. A redescription of Chaetozone setosa Malmgren, 1867 including a definition of the genus, and a description of a new species of Chaetozone (Polychaeta: Cirratulidae) from the northeast Atlantic. Bulletin of Marine Science 67, 587-596.

Chambers S.J. \& Woodham A. 2003. A new species of Chaetozone (Polychaeta: Cirratulidae) from deep water in the northeast Atlantic, with comments on the diversity of the genus in cold northern waters. Hydrobiologia 496, $41-48$.

Cochrane S.J. 2000. Taxonomy and systematics of selected marine soft-bottom fan-worms (Polychaeta: Sabellidae: Sabellinae). PhD thesis, University of St. Andrews.

Ditlevsen H. 1917. The Danish Ingolf-Expedition. Vol. 4. Part 4. Annelids. I. Copenhagen: H. Hagerup.

Eibye-Jacobsen D. 1991. A revision of Eumida Malmgren, 1865 (Polychaeta: Phyllodocidae). Steenstrupia 17, 81-140.

Eliason A. 1955. Neue oder wenig bekannte Schwedische Ampharetiden (Polychaeta). (New and lesser known Apmpharetidae from Sweden.) Göteborgs Kungliga Vetenskaps- och vitterhetssamhälles Handlingar 6(16), 1-17.
Eliason A. 1962. Die polychaeten der Skagerak-Expedition 1933. (Polychaetes from the Skagerak Expedition in 1933.) Zoologiska Bidrag, Uppsala 33, 207-293.

Fauvel P. 1913. Campagne de Pourquoi-Pas? (Island et Jan Mayen, 1912). Annelidés Polychètes. (The Pourquoi-Pas? Expedition. [Iceland and Jan Mayen, 1912]. Annelida, Polychaeta.) Bulletin de Muséum d'Histoire Naturelle, Paris 2, 80-93.

Fauvel P. 1923. Polychètes errantes. (Polychaeta errantia.) Faune de France 5. Paris: P. Lechevalier.

Fauvel P. 1927. Polychètes sedentaires. Addenda aux Errantes, Archiannélides, Myzostomaires. (Polychaeta sedentaria. With supplement on errantia, Archiannelida, Myzostomida.) Faune de France 16. Paris: P. Lechevalier.

Fauvel P. 1946. Annélides Polychètes des Croisières du Pourquoi-Pas? (Annelida Polychaeta from cruises with the Pourquoi-Pas?) Bulletin du Muséum d'Histoire Naturelle, Paris 18(5), 397-403.

Fitzhugh K. 1989. A systematic revision of the Sabellidae-Caobangiidae-Sabellongidae complex (Annelida: Polychaeta). Bulletin of the American Museum of Natural History 192. New York: American Museum of Natural History.

Frame A.B. 1992. The lumbrinerids (Annelida: Polychaeta) collected in two northwestern Atlantic surveys with descriptions of a new genus and two new species. Proceedings of the Biological Society of Washington 105, 185-218.

Furreg E. 1925. Zur Systematik der Polychätenfamilie Scalibregmidae. (On the systematics of the polychaete family Scalibregmidae.) Zoologische Jahrbücher, Abteilung für Systematik, Geographie und Biologie der Tiere 50(2), 123-190.

Gabrielsen G.W., Brekke B., Alsos I.G. \& Hansen J.R. 1997. Natur-og kulturmiljøet på Jan Mayen. (The nature and cultural environment on Jan Mayen.) Norsk Polarinstitutt Meddelelser 144. Oslo: Norwegian Polar Institute.

George J.D. \& Hartmann-Schröder G. 1985. Polychaetes: British Amphinomida, Spintherida and Eunicida. Synopsis British Fauna New Series 32. London: E.J. Brill.

Gulliksen B. 1974a. Marine investigations at Jan Mayen. Kongelige Norske Videnskabers Selskab Museet, Miscellanea 19 , $1-46$.

Gulliksen B. 1974b. Ascidians of Jan Mayen. Astarte 7, 67-70.

Gulliksen B., Beuchel F., Brattegard T. \& Palerud R. 2004. The marine sublittoral fauna of Jan Mayen. Zoogeography and succession on "New" lava grounds. In S. Skreslet (ed.): Jan Mayen island in scientific focus. Pp. 159-171. Dordrecht: Kluwer Academic Publishers.

Gulliksen B., Haug T. \& Sandnes O.K. 1980. Benthic macrofauna on new and old lava grounds at Jan Mayen. Sarsia 65, 137-148.

Gulliksen B., Palerud R., Brattegard T. \& Sneli, J.-A. (eds.) 1999. Distribution of marine benthic macro-organisms at Svalbard (including Bear Island) and Jan Mayen. Research Report for DN 1999-4. Trondheim: Directorate for Nature Management. 
Hansen G.A. 1879a. Annelider fra den norske Nordhavsexpedition i 1876. (Annelids from the Norwegian northern seas expedition in 1876.) Nyt Magazin for Naturvidenskaberne 24, 1-17.

Hansen G.A. 1879b. Annelider fra den norske Nordhavsexpedition i 1877. (Annelids from the Norwegian northern seas expedition in 1877.) Nyt Magazin for Naturvidenskaberne 24, 267-272.

Hansen G.A. 1880. Annelider fra den norske Nordhavsexpedition i 1878. (Annelids from the Norwegian northern seas expedition in 1878.) Nyt Magazin for Naturvidenskaberne 25, 224-234.

Hansen G.A. 1882. Annelida. The Norwegian North-Atlantic Expedition 1876-1878. VII. Vol. 3. Zoology. Christiania: Gröndahl \& Søn.

Hartman O. \& Fauchald K. 1971. Deep-water benthic polychaetous annelids off New England to Bermuda and other North Atlantic Areas. Part II. Allan Hancock Monographs in Marine Biology 6. Los Angeles: University of Southern California Press.

Hartmann-Schröder G. 1996. Annelida, Borstenwürmer, Polychaeta. 2. Neubearbeitete Auflage. Die Tierwelt Deutschlands 58. (Annelida, bristleworms, Polychaeta. 2 The Fauna of Germany. Revised edition.) Jena: Gustav Fischer.

Holthe T. 1986. Polychaeta Terebellomorpha. Marine Invertebrates of Scandinavia 7. Oslo: Norwegian University Press.

Imajima M. \& Shiraki Y. 1982. Maldanidae (Annelida: Polychaeta) from Japan. Part 2. Bulletin of the National Science Museum, Tokyo 8(2), 47-88.

Johansson K.E. 1927. Beiträge zur Kenntnis der Polychaeten-Familien Hermellidae, Sabellidae und Serpulidae. (Contributions to knowledge of the polychaete family Hermellidae, Sabellidae and Serpulidae.) Zoologiska Bidrag från Uppsala 11. Stockholm: Almqvist \& Wiksell Periodical Co.

Kato T. \& Pleijel F. 2003. A revision of Paranaitis Southern, 1914 (Polychaeta: Phyllodocidae). Zoological Journal of the Linnean Society 138, 379-429.

Kirkegaard J.B. 1982. New records of abyssal benthic polychaetes from the Polar Sea. Steenstrupia 8(10), 253-260.

Kirkegaard J.B. 1996. Havbørsteorme II. (Marine bristleworms II.) Danmarks Fauna 86. Copenhagen: Danish Natural History Society.

Koh B.-S., Bhaud M.R. \& Jirkov I.A. 2003. Two new species of Owenia (Annelida: Polychaeta) in the northern part of the Atlantic Ocean and remarks on previously erected species from the same area. Sarsia 88 , 175-188.

Knight-Jones P. \& Knight-Jones E.W. 1977. Taxonomy and ecology of British Spirorbidae (Polychaeta). Journal of the Marine Biological Association of the UK 57, 453-499.

Knight-Jones P., Knight-Jones E.W. \& Buzhinskaya G. 1991. Distribution and interrelationships of northern spirorbid genera. Bulletin of Marine Science 48(2), 189-197.

Knight-Jones P. \& Perkins T.H. 1998. A revision of Sabella, Bispira and Stylomma (Polychaeta: Sabellidae). Zoological Journal of the Linnean Society 123, 385-467.
Lønne O.J. (ed.) 1999. AB-301A. Marine benthic fauna of Svalbard, 1999. Cruise report. Longyearbyen: University Courses on Svalbard.

Loshamn A.-A. 1980. En systematisk og dyregeografisk undersøkelse over skjellrygg-gruppen (Familie Aphroditidae sensu Fauvel 1923). (A systematic and zoogeographical investigation of the scale-worm group [Family Aphroditidae sensu Fauvel 1923].) Cand. real. thesis, University of Oslo.

Maciolek N.J. 1990. A redescription of some species belonging to the genera Spio and Microspio (Polychaeta: Annelida) and descriptions of three new speciesfrom the northwestern Atlantic Ocean. Journal of Natural History 24, 1109-1141.

Mackie A.S.Y. 1984. On the identity and zoogeography of Prionospio cirrifera Wirén, 1883 and Prionospio multibranchiata Berkely, 1927 (Polychaeta; Spionidae). In P.A. Hutchings (ed.): Proceedings of the First International Polychaete Conference, Sydney. Pp. 34-47. Sydney: Linnean Society of New South Wales.

Mackie A.S.Y. \& Pleijel F. 1995. A review of the Melinna cristata-species group (Polychaeta: Ampharetidae) in the northeastern Atlantic. Mitteilungen aus dem Hamburgischen Zoologischen Museum und Institut 92 (Ergänzungsband 1), 103-124.

Malmgren A.J. 1867. Annulata polychaeta Spetsbergiæe, Grönlandiæ, Islandiæ et Scandinaviæ hactenus cognita. (Present knowledge of Annelida Polychaeta from Greenland, Iceland and Scandinavia.) Öfversikt af Kongliga Vetenskaps-Akedemiens Förhandlingar 24, 127-235.

Möbius K. 1874. Mollusken, Würmer, Echinodermen und Coelenteraten. Die Zweite Deutsche Nordpolarfarht in die Jahren 1869 und 1870 unter fürung Kapitän Karl Koldewey. (Molluscs, worms, echinoderms and coelentrates. The second German north polar expedition during the years 1869 and 1870 under the leadership of Captain Karl Koldeway.) Leipzig: Wissenschaftliche Ergenbnisse.

Nilsen R. \& Holthe T. 1985. Arctic and Scandinavian Oweniidae (Polychaeta) with a description of Myriochele fragilis sp. n., and comments on the phylogeny of the family. Sarsia 70, 17-32.

Nygren A., Pleijel F. \& Sundberg P. 2005. Genetic relationships between Nereimyra punctata and $N$. woodsholea (Hesionidae, Polychaeta). Journal of Zoological Systematics and Evolutionary Research 43, 273-276.

Orensanz J.M. 1990. The eunicemorph polychaete annelids from Antarctic and subantarctic seas. With addenda to the Eunicemorpha of Argentina, Chile, New Zealand, Australia, and the southern Indian Ocean. Antarctic Research Series 52. Washington, D.C.: American Geophysical Union.

Oug E. 2000. An annotated list of polychaetous annelids from the region of Tromsø, northern Norway. In E. Oug: The marine benthic fauna in the region of Tromsø, northern Norway, with particular reference to bristle worms (Annelida: Polychaeta). PhD thesis, University of Tromsø.

Parapar J. 2003. Oweniidae (Annelida, Polychaeta) from Icelandic waters, collected by the BIOICE project, with a description of Myrioglobula islandica n. sp. Sarsia 88, 274-290. 
Petersen M.E. 1998. Pholoe (Polychaeta: Pholoidae) from northern Europe: a key and notes on the nearshore species. Journal of the Marine Biological Association of the UK 78, 1373-1376.

Pettibone M.H. 1954. Marine polychaete worms from Point Barrow, Alaska, with additional records from the North Atlantic and North Pacific. Proceedings of the United States National Museum 103, 203-356.

Pettibone M.H. 1963. Marine polychaete worms of the New England region. I. Aphroditidae through Trochochaetidae. Bulletin of the United States National Museum 227, 1-356.

Pettibone M.H. 1976. Revision of the genus Macellicephala McIntosh and the subfamily Macellicephalinae Hartmann-Schröder (Polychaeta: Polynoidae). Smithsonian Contributions to Zoology 229. Washington, D.C.: Smithsonian Institution Press.

Pettibone M.H. 1993. Revision of some species referred to Antinoe, Antinoella, Antinoana, Bylgides, and Harmothoe (Polychaeta: Polynoidae: Harmothoninae). Smithsonian Contributions to Zoology 545. Washington, D.C.: Smithsonian Institution Press.

Pleijel F. 1993. Polychaeta Phyllodocidae. Marine Invertebrates of Scandinavia 8. Oslo: Norwegian University Press.

Rainer S.F. 1991. The genus Nephtys (Polychaeta: Phyllodocida) of northern Europe: a review of species, including the description of N. pulchra sp. n. and a key to the Nephtyidae. Helgoländer Meeresuntersuchungen 45, 65-96.

Sars M. 1851. Beretning om en i sommeren 1849 foretagen zoologisk reise i Lofoten og Finmarken. (Accounts from a zoological journey to Lofoten and Finnmark in 1849.) $N y t$ Magazin for Naturvidenskaberne, Christiania 2(2), 121-211.

Sars M. 1862. Foredrag om de ved Norges Kyster forekommende Arter af den Linnéiske Annelideslægt Sabella. (Lecture on current species in the annelid genus Sabella, described by Linné.) Forhandlinger fra Videnskabs-Selskabet i Christiania 1862, 116-133.

Sigvaldadottír E. 2002. Polychaetes of the genera Prionospio and Aurospio (Spionidae, Polychaeta) from Icelandic waters. Sarsia 87, 207-215.

Skjæeveland S.H. 1973. Echinoderms of Jan Mayen. Astarte 6, 69-74.

Sneli J.-A. 1977. Jan Mayen molluscs. Malacologia 16, 257-260.

Sneli J.-A. 1998. A simple benthic sledge for shallow deep-sea sampling. Sarsia 83, 69-72.

Sneli J.-A. \& Steinnes A. 1975. Marine mollusca of Jan Mayen Island. Astarte 8, 7-16.

Söderström A. 1920. Studien über die Polychätenfamilie Spionidae. (Study of the polychaete family Spionidae.) Uppsala: Uppsala University.

Solbakken B.E.B. 2002. Familien Orbiniidae (Polychaeta) $i$ nordiske og tilgrensende arktiske farvann. (The family Orbiniidae
[Polychaeta] in Nordic and adjacent Arctic waters.) Cand. scient. thesis, Norwegian University of Science and Technology.

Støp-Bowitz C. 1945a. Les Ophéliens Norvégiens. (The opheliids of Norway.) Nytt Magasin for Naturvidenskapene 85, 21-61.

Støp-Bowitz C. 1945b. Les Scalibregmiens de Norvège. (The scalibregmids of Norway.) Nytt Magasin for Naturvidenskapene 85, 63-87.

Sundfjord A., Fer I., Kasajima Y. \& Svendsen H. 2007. Observations of turbulent mixing and hydrography in the marginal ice zone of the Barents Sea. Journal of Geophysical Research-Oceans 112, C05008, doi: 10.1029/ 2006JC003524.

Tendal O.S. 1983. Sponges of Jan Mayen. Astarte 12, 53-55. Théel H.J. 1879. Les Annélides Polychètes des mers de la Nouvelle-Zemble. (Polychaetous annelids from the waters around Novaya Zemblya.) Kungliga Svenska vetenskapsakademiens handlingar 16(3), 1-75.

Thulin G. Über einige Spioniden (Polychaeta) aus dem Öresund. (On a spionid [Polychaeta] from Öresund.) Kungliga Fysiografiska Sällskapets i Lund Föhandlingar 27(5), 49-59.

von Marenzeller E. 1886. Poriferen, Anthozoen, Ctenophoren und Würmer von Jan Mayen. Die Österreichische Polarstation Jan Mayen (Poriferans, ctenophores and worms from Jan Mayen. The Austrian Polar station Jan Mayen.) Beobachtungs-Ergebnisse Herausgeben von der Kaiserlichen Akademie der Wissenschaften 3, 9-24.

Warren L.M. 1991. Problems in capitellid taxonomy. The genera Capitella, Capitomastus and Capitellides (Polychaeta). Ophelia Suppl. 5, 275-282.

Wesenberg-Lund E. 1947. Syllidae (Polychaeta) from Greenland waters. Meddelelser om Gronland 134(6). Copenhagen: Commission for Scientific Research in Greenland.

Wesenberg-Lund E. 1950. Polychxta. The Danish Ingolf-Expedition. Vol. 4. Part 14. Copenhagen: Bianco Luno.

Wesenberg-Lund E. 1953. The zoology of East Greenland. Polychaeta. Meddelelser om Grønland 122(3). Copenhagen: Commission for Scientific Research in Greenland.

Wolf P.S. 1984. Family Maldanidae Malmgren, 1867. In J.M. Uebelacker \& P.G Johnson (eds.): Taxonomic guide to the polychaetes of the northern Gulf of Mexico. Final report to the Minerals Management Service, contract 14-12-001-29091. Vol. 2. Pp. 15.1-15.21. Mobile: Barry A. Vittor \& Associates.

Worsaae K. 1999. On the taxonomy of Spio filicornis (Spionidae, Polychaeta)—Nipisat, Disko, Greenland. Berichte zur Polarforschung 330, 164-169.

Žadan A.È. 1998. Taksonomija polihet roda Scoloplos (Orbiniidae) v Belom, Barencevom i Severnom morjah. (Taxonomy of the polychaete genus Scoloplos Blainville, 1828 [Orbiniidae] in the White, Barents and North seas.) Zoologičeskij Žurnal 77, 177-190. 